\title{
THE ENFORCEMENT OF THE CANADIAN CHARTER OF RIGHTS AND FREEDOMS: AN ANALYSIS OF SECTION 24*
}

\author{
A. ANNE McLELLAN AND \\ BRUCE P. ELMAN**
}

\section{INTRODUCTION}

Grand-sounding and often abstract principles declaring the existence of fundamental human freedoms are meaningless absent effective means for their enforcement. In discussing his third element of the "rule of law", Dicey points out the absolute necessity of providing adequate remedies to secure the right to individual liberty. He states: ${ }^{2}$

... the question whether the right to personal freedom . . . is likely to be secure depends a good deal upon the answer to the inquiry whether the persons who consciously or unconsciously build up the constitution of their country begin with definitions or declarations of rights, or with the contrivance of remedies by which rights may be enforced or secured. Now, most foreign constitution-makers have begun with declarations of rights. . . . But any knowledge of history suffices to show that foreign constitutionalists have, while occupied in defining rights, given insufficient attention to the absolute necessity for the provision of adequate remedies by which the rights they proclaimed might be enforced.

H.W. Jones in an article on "The Rule of Law and the Welfare State" has restated Dicey's third element of the "rule of law" as follows:"

... effective judicial remedies are more important than abstract constitutional declarations in securing the rights of the individual against encroachment by the state.

Section 24 of the Canadian Charter of Rights and Freedoms provides the means whereby anyone who has suffered an alleged violation of his or her rights may apply to a court of competent jurisdiction for a remedy. Section 24 states: ${ }^{4}$

(1) Anyone whose rights or freedoms, as guaranteed by this Charter, have been infringed or denied may apply to a court of competent jurisdiction to obtain such remedy as the court considers appropriate and just in the circumstances.

(2) Where in proceedings under subsection (1), a court concludes that evidence was obtained in a manner that infringed or denied any rights or freedoms guaranteed by this Charter, the evidence shall be excluded if it is established that, having regard to all the circumstances, the admission of it in the proceedings would bring the administration of justice into disrepute.

* This article was originally prepared for presentation at a series of seminars on the Charter of Rights and Freedoms held in December, 1982, and sponsored by the Friends of the Faculty of Law of the University of Alberta. The authors would like to thank Professor Paul Bender of the University of Pennsylvania and Professor Gerald L. Gall of the University of Alberta for their extensive comments on an earlier draft of this paper.

* * Both authors are of the Faculty of Law, University of Alberta.

1. Dicey, Introduction to the Study of the Law of the Constitution, (10th ed., by E.C.S. Wade). Dicey's third element of the "rule of law" states: "the law of the constitution is not the source but the consequence of the rights of individuals as defined and enforced by the courts" (at 203).

2. Id., at 198.

3. Jones, "The Rule of Law and the Welfare State" (1958) 58 Colum. L. Rev. 143 at 150.

4. Constitution Act, 1982. 
The Canadian Bill of Rights (1960) was notable for the absence of such a section, resulting in a majority of the Supreme Court of Canada taking the position that their remedial powers were limited to declaring challenged legislation inoperative to the extent of any inconsistency with the Bill of Rights. ${ }^{5}$ Indeed, the statutory mandate assigned to the courts was only to construe and apply legislation so as to not abridge or infringe any of the rights contained therein. ${ }^{6}$ Consequently, remedial measures, such as the exclusion of evidence, were not granted by the Supreme Court of Canada for a Bill of Rights violation. ${ }^{\text {? }}$

Professor Walter Tarnopolsky appearing before the Special Joint Committee on the Constitution of Canada, made the following comments on the lack of an enforcement section in the Canadian Bill of Rights: ${ }^{8}$

Ordinarily one would expect that when a Bill of Rights sets out certain rights and freedoms, that a remedy would be presumed. In other words, our Courts would not be moved to assert there is a right unless there is a remedy, but if I could take you back brief ly to the Supreme Court decision in the Hogan case, you will note that the majority of our Supreme Court has not followed that kind of logical conclusion. In the Hogan case, although all members of the Supreme Court did say that the denial of counsel to Hogan was a contravention of the right to counsel in the Canadian Bill of Rights, the majority went on to say that there was not a remedy written out in the Bill of Rights and they did not have to devise one, and certainly they saw no reason to adopt the American exclusionary rule because, they said, the system in the United States was different.

Other witnesses before the Special Joint Parliamentary Committee supported Professor Tarnopolsky's position. ${ }^{9}$

In this paper the history of section 24 will be briefly considered. Further, an analysis of the possible interpretations of subsections (1) and (2) will be undertaken. Finally, some comments on the application of section 32 will be advanced.

\section{HISTORY OF SECTION 24}

The enforcement provision of the Charter went through a number of major revisions before ultimately being approved by the Special Joint Committee and the Parliament of Canada in the form in which it now appears in the Charter of Rights and Freedoms. In Bill C-60, An Act to Amend the Constitution of Canada, the following enforcement provision was proposed: ${ }^{10}$

5. R. v. Drybones [1970] S.C.R. 282 , in which s. 94(b) of the Indian Act was declared inoperative.

6. Canadian Bill of Rights, S.C. 1960, c. 44, s. 2.

7. See Hogan v. The Queen [1975] 2 S.C.R. 574, (1975) 62 D.L.R. (3d) 193, 18 C.C.C. (2d) 65.

8. Special Joint Committee on the Constitution of Canada Proceedings, 32nd Parl., Sess. $1(1980-81)$, No. 7 at 15.

9. Id. at 99-100 for the following comments by Professor Joseph Magnet, Special Advisor, Canadian Jewish Congress:

.. the Hogan case in the Supreme Court of Canada recognized the violation of legal rights under the Diefenbaker Bill of Rights, the court said: Well, we see no remedy clause here, we cannot grant a remedy.

... we think that to deal with problems like this, as well as the panoply of rights which would be entrenched in the Charter, an enforcement clause is crucial, that the Charter would be hollow without it, and we think that this is in comformity with our international obligation under the Covenant on Civil and Political Rights ... .

10. Bill C-60 was introduced by the Liberal Government of Pierre Trudeau in June 1978. See Canada, House of Commons, Bill C.60, 3rd Sess., 30th Parl., 26-27 Eliz. II, 1977-78. 
24. Where no other remedy is available or is provided by law, any individual may, in accordance with the applicable procedure of any court in Canada of competent jurisdiction, request the court to define or enforce any of the individual rights and freedoms declared by this Charter, as they extend or apply to him or her, by means of a declaration of the court or by means of an injunction or similar relief, accordingly as the circumstances require.

This section clearly envisioned a very limited range of remedies for the violation of Charter rights and was severely criticized by civil liberties groups. Also there was no provision for the exclusion of evidence.

By the summer of 1980 , a revised enforcement section was presented by the federal government for provincial consideration. It read:

Where no other effective recourse or remedy is available or provided for by law, anyone whose rights or freedoms as declared by this Charter have been infringed or denied to his or her detriment, has the right to apply to a court of competent jurisdiction to obtain such relief or remedy as the court deems appropriate and just in the circumstances.

When this section was proposed, there was concern on the part of the provinces that it would permit the adoption of the American exclusionary rule into Canadian law. Therefore, to supplement the above section, a new section was proposed which read: ${ }^{11}$

26. No provision of this Charter, other than section 13 , affects the laws respecting admissibility of evidence in any proceedings or the authority of Parliament or a legislature, to make laws in relation thereto.

In fact, this section had the effect of reinforcing the existing law in respect of the admissibility of evidence, and in particular, maintained the principles concerning admissibility developed by the Supreme Court of Canada in Regina v. Wray. ${ }^{12}$

Civil liberties associations voiced strong opposition to such a provision. Professor Walter Tarnopolsky, appearing before the Special Joint Committee on behalf of the Canadian Civil Liberties Association made the following comments in relation to the proposed section $26:^{13}$

... What the Supreme Court then said was that they could not find in the Canadian Bill of Rights a reason to override the longstanding rule of evidence, that evidence if obtained even illegally is admissible if relevant. Now, that, Mr. Chairman, we suggest is exactly what s. 26 enshrines. Section 26 enshrines the rule that evidence, even if illegally obtained, is admissible if relevant and I cannot imagine a Bill of Rights that we would want to hold up proudly in the world having that kind of provision specifically protected.

Professor Tarnopolsky recommended that the Committee go back to the version proposed in the summer of 1980, thereby deleting any specific reference to the admissibility of evidence. In light of responses such as Professor Tarnopolsky's, and many others, the then Minister of Justice, Jean Chretien, when he appeared before the Committee in January 1981,

11. "Proposed Resolution for a Joint Address to Her Majesty the Queen Respecting the Constitution of Canada", tabled in the Senate and House of Commons on October 2, 1980. It should be noted that $\mathrm{s}$. 24 as originally proposed in Bill C - 60 did not appear in the Joint Resolution tabled in October, 1980. In fact, there was no equivalent enforce. ment section. This provoked Professor Tarnapolsky's criticism discussed infra n. 13 and accompanying text.

12. Regina v. Wray [1971] S.C.R. 272, [1970] 4 C.C.C. 1; reug. [1970] 3 C.C.C. 122 (Ont. C.A.).

13. Special Joint Committee on the Constitution of Canada, supra n. 8 at 15 . 
agreed to delete Section 26, dealing with admissibility of evidence. ${ }^{14}$ However, after further submissions by members of the Progressive Conservative Party and the New Democratic Party, revisions were made to give the courts specific direction to exclude evidence in certain circumstances, thereby implicitly overruling, in part, the majority decision of the Supreme Court of Canada in Regina v. Wray. ${ }^{15}$ These submissions eventually resulted in the present section $24(2)$.

At the same time, the Minister of Justice indicated the Government's willingness to see a remedies section included. The section he proposed at the time was eventually approved by Parliament and now constitutes the existing section $24(1){ }^{16}$

\section{ANALYSIS OF SECTION 24(1)}

\section{A. "ANYONE"}

A number of different terms are used in the Charter to describe to whom various rights are extended. For instance, section 2 speaks of "everyone"; section 3 speaks of "every citizen"; section 11 speaks of "any person"; section 15 speaks of "every individual". Section 24 extends the right to seek a remedy to "anyone" who has had a right or freedom as guaranteed by the Charter infringed or denied. It is submitted that the term "anyone" will bear the same meaning as "everyone" and it seems clear that "everyone" includes not only natural persons but bodies corporate and other collective associations. ${ }^{17}$ For example, the Criminal Code of Canada, section 2, defines "everyone" and similar expressions to include among others, bodies corporate and societies.

It is also clear from testimony before the Special Joint Committee, that it was intended that the terms "every person" and "everyone" include, not

14. Special Joint Proceedings, supra n. 8, No. 36 at 18. Then Minister of Justice Chretien's proposal to the Committee was in the following terms:

Evidence:

The Canadian Bar Association, the Canadian Civil Liberties Association, the Chief Commissioner of the Canadian Human Rights Commission and others have expressed their opposition to Section 26 of the draft resolution which states that the Charter will not affect laws respecting the admissibility of evidence. In light of the criticisms, the government is prepared to drop the section.

15. For example, see Special Joint Proceedings, supra n. 8, No. 36 at 120-125.

16. Special Joint Proceedings, supra n. 8, No. 366 at 19. Then Minister of Justice Chretien's proposal to the Committee was in the following terms:

Remedies:

The Canadian Civil Liberties Association, the Canadian Jewish Congress, many members of this Committee and other witnesses expressed the strong view that the Charter requires a remedies section. This would ensure that the Courts could order specific remedies for breach of Charter rights.

I would be prepared to see a new section stating that:

Anyone whose rights or freedoms, as guaranteed by this Charter, have been infringed or denied may apply to a court of competent jurisdiction to obtain such remedy as the court considers just and appropriate in the circumstances.

This would ensure that an appropriate remedy as determined by the courts would be afforded to anyone whose rights have been infringed whether through enactment of a law or by an action of a government official.

17. In Union Colliery v. The Queen (1900) 31 S.C.R. 81, Sedgewick J. said at 88: "Everyone is an expression of the same kind as person, and thereby includes bodies corporate unless the context requires otherwise." 
only human beings, but corporate entities, ${ }^{18}$ and it is reasonable to assume the term "anyone" will be given the same meaning.

Therefore one can anticipate that the word anyone will be interpreted by the courts to include not only natural persons but corporate and other legal entities who have suffered violations of their rights. ${ }^{19}$

\section{B. "WHOSE RIGHTS OR FREEDOMS AS GUARANTEED BY THIS CHARTER HAVE BEEN INFRINGED OR DENIED"}

Section 24(1) provides a remedy only in relation to the violation of Charter rights. For alleged violations of rights other than those guaranteed in the Charter, aggrieved persons must seek other avenues of redress. For example, if a person's right to enjoy property is allegedly infringed, an application under section 24(1) would be inappropriate and a remedy would have to be found elsewhere. ${ }^{20}$

Section 24(1) contains a non-discretionary, statutory standing provision. Only one whose personal rights or freedoms have been actually infringed or denied can bring an application under section 24(1). This clearly creates a test for standing which is more restrictive than that recently articulated by the Supreme Court of Canada in the case of Minister of Justice (Can.) v. Borowski. ${ }^{21}$

Mr. Justice Martland delivered the majority judgment in Borowski and enunciated the following test to determine standing when an applicant is seeking to attack the constitutional validity of an enactment: ${ }^{22}$

\footnotetext{
... to establish status as a plaintiff in a suit seeking a declaration that legislation is invalid, if there is a serious issue as to its invalidity, a person need only to show that he is affected by it directly or that he has a genuine interest as a citizen in the validity of the legislation and that there is no other reasonable and effective manner in which the issue may be brought before the Court.
}

Mr. Borowski was granted standing by a majority of the Supreme Court of Canada on the basis of Mr. Justice Martland's test. ${ }^{23}$ To briefly summarize the facts of this very interesting case: over the past ten years, Joe Borowski has conducted a one-man crusade to seek the repeal of section 251(4), (5) and (6) of the Criminal Code which exempts qualified medical practitioners from criminal liability if they perform abortions under certain defined conditions. Mr. Borowski maintains that section 251(4), (5) and (6) infringe the right to life as declared in section 1(b) of the Bill of

18. For example, see the comments of Robert Kaplan, M.P., and Bryce Mackasey, M.P., before the Special Joint Committee on the Constitution of Canada, supra n. 8, No. 43, at 41.53 .

19. In a recent unreported decision of the Alberta Court of Queen's Bench, The Queen and G.B., a Juvenile v. Edmonton Journal, Dea J. made the following comment at 3 of the judgment:

At the outset let me say that in my view "anyone" includes a corporation and is not to be restricted to a human person.

20. This assumes that property rights are not protected in the Charter. A person could then argue for protection of his right to enjoy property on the basis of either the Alberta Bill of Rights, or the Canadian Bill of Rights, if the subject matter of the alleged violation was within federal jurisdiction.

21. [1981]2 S.C.R. 575 .

22. Id. at 598.

23. The decision was 7-2 in favour of granting Mr. Borowski standing. Laskin C.J.C. and Lamer J. dissented. For a critical analysis of the Borowski case, see a note by Karen Swartzenberger, (1982) 20 Alta. L. Rev. 503. 
Rights. Mr. Borowski's crusade has been a long and a passionate one. ${ }^{24}$ There can be no question that he is a citizen with a genuine interest in having the validity of the legislation tested. In addition, a majority of the Supreme Court of Canada felt there was no other reasonable and effective manner in which the issue was likely to be brought before the courts. ${ }^{25}$ However, genuine interest will not be enough to be granted standing under section 24(1) of the Charter. As noted above, the words of the subsection expressly exclude the Joe Borowski's who have not had a right or freedom personal to them infringed or denied, and, who in fact, seek a declaration of invalidity merely on the basis of principle or to champion the cause of others.

The choice of the past tense in the phrase "whose rights . . have been infringed or denied" (emphasis added) may indicate that only persons who have allegedly suffered a violation of some right at the time of the application will be granted standing. This would preclude an application to seek a remedy in relation to an imminent or impending violation. While the words of the section support this narrow interpretation, it is submitted that it would be most unfortunate if the courts ultimately were to adopt this view. The Charter is a constitutional document, declaring and guaranteeing certain rights and freedoms, and should be interpreted in a broad and liberal manner to maximize the protection of a person's rights and freedoms ${ }^{26}$ Therefore, it is suggested that courts should include within the scope of section 24, applications to prevent apprehended or impending

24. Mr. Borowski resigned a Cabinet post in the Manitoba government of then Premier Edward Schreyer to protest the use of Manitoba tax dollars in performing therapeutic abortions. He also commenced a highly publicized hunger strike and asked the Pope to intercede on his behalf with the Prime Minister of Canada.

25. Martland J. discussed in some detail, at 596-598 of his judgment, why the majority of the Court felt there was no class of person directly affected or exceptionally prejudiced by the legislation who would have cause to attack the legislation. He considered the position of doctors, hospitals, pregnant mothers, husbands of pregnant wives desiring abortions and the unborn foetus itself.

Laskin C.J.C. (Lamer J. concurring) took a different approach on this issue. At 584 of the judgment, he states:

The only question that remains is whether, neither the Thorson case nor the McNeil case being strictly applicable according to the character of the legislation there and here, this is an appropriate case for the Court to exercise its discretion to accord standing. My reason for distinguishing the legislative situation is that here there are persons with an interest in the operation of s. 251(4), (5) and (6) who might challenge it as offending the Canadian Bill of Rights. I refer to doctors and to hospitals, both having a clearer interest in the operation of s. 251(4), (5) and (6) than does the plaintiff. Husbands who might object to their pregnant wives seeking a therapeutic abortion also have a clearer interest. It may be that in their case there would be a dilemma, having regard to the inexorable progress of a pregnancy. In short, even if the statutory requirements for a therapeutic abortion were satisfied, it might be difficult to initiate and exhaust the judicial processes to obtain a ruling as to the compatability of s. 251(4), (5) and (6) with the Canadian Bill of Rights before the abortion or birth, as the case might be, takes place. In principle, however, this should not be preclusive; the point will have been decided at the instance of a person having an interest and not at that of a person having no interest other than as a citizen and taxpayer.

26. See, Edwards \& Others v. A.G. Canada \& Others [1930] A.C. 124; Minister of Home Affairs v. Fisher [1980] A.C. 319; Southam, Inc. v. Lawson A.W. Hunter, Director of Investigation and Research of the Combines Investigation Branch and Others, an unreported judgment of the Alberta Court of Appeal, delivered at Edmonton, January 31, 1983; Quebec Association of Protestant School Boards v. Attorney-General of Quebec (No. 2) (1983) 140 D.L.R. (3d) 33 (P.Q.S.C.). 
violations. Chief Justice Jules Deschênes briefly dealt with this issue in Quebec Association of Protestant School Boards v. The Attorney General of Quebec (No. 2) in which he commented:"27

The applicants are worried about the situation with respect to the registration of children for the school year beginning in September, 1982. Their application does not allege any past violations: it concerns future application of the legal provisions at issue.

However, at least in the English version, s. 24 of the Charter would appear to refer to the past only: "Anyone whose rights or freedoms, as guaranteed by this Charter, have been infringed or denied. ..".

Professor Hogg also notes this difficulty, but he suggests a solution:

The section also contemplates that the infringement has occurred by the time of the applica. tion; it does not authorize an application in respect of a merely apprehended future infringement. However, the liberal approach of the Supreme Court of Canada to standing in constitu. tional cases (see especially Borowski v. Minister of Justice of Canada [1980] 6 W.W.R. 153, 6 Sask. R. 311) may well spill over into s. 24 applications, leading the court to assume a discretionary power to grant standing in cases not literally covered by s. 24 .

For this reason, but also for various other reasons, the court is of the opinion that it is in order to extend the scope of s. 24 to the future as to the past.

Although Chief Justice Deschenes' comments are obiter, his view is attractive. There may be situations where grave harm or irreparable damage will result to an individual if a court refuses to entertain an application based on an anticipated violation. An example can be constructed on the basis of Bill 101, the Quebec Language Charter. If such legislation were passed by the Quebec Legislature, but were not to be proclaimed in force until a future date, there would be no actual violation of the rights of English-speaking students, as guaranteed by section 23 of the Charter. However, it is suggested that this is a case where a court should entertain an application on behalf of the parents, or the children themselves, on the basis that an infringement is imminent. To wait until actual infringement of a child's rights has occurred will likely disrupt, if not destroy entirely, a year of schooling for a child who has the constitutional right to be educated in the English language. Therefore, in situations of this kind the courts should be encouraged to hear applications, although no actual infringement of a guaranteed Charter right has occurred at the date of the application. ${ }^{28}$

27. Quebec Association of Protestant School Boards, id. at 41-42. It should be noted Chief Justice Deschenes finally concluded that the alleged infringement was no longer merely "apprehended". He stated at 43:

the future is already here. The beginning of the school year has come and it would be ridiculous now to reject this application, which the court heard for seven days from August 9 to 17, 1982, for the sole reason that it could not be heard before the beginning of September, particularly when the interests of those principally affected, the children, require a prompt decision.

28. Professor Dale Gibson in an article entitled "Enforcement of the Canadian Charter of Rights and Freedoms" in Canadian Charter of Rights and Freedoms - Commentary, (1982, Walter S. Tarnopolsky and Gerald A. Beaudoin eds.) sets out the following examples of possible impending infringements at 498:

One is the sort of situation that gave rise to the Saumur case referred to earlier: a law prohibiting the exercise of some freedoms that the complainant would like to exercise but not at the cost of criminal prosecution. Another would be a law empowering authorities to infringe rights or freedoms in some arbitrary fashion, such as by randomly searching homes in the hope of finding evidence of illegal activity, which has not yet been employed against the complainant. A third would be a situation where police or other authorities are planning to take a measure like those in the previous example, but without lawful authority, and have not yet acted. Finally, a legislative body, municipal, provincial or federal, might simply be debat. ing the desirability of passing a law that some would believe would violate the Charter. 


\section{The Relationship Between Section 24(1) of the Charter and Section 52(1) of the Constitution Act, 1982}

The relationship between section 24(1) of the Charter and section 52(1) of the Constitution Act, 1982 must be considered. Section 52(1) declares that "the Constitution of Canada is the supreme law of Canada and any law that is inconsistent with the provisions of the Constitution is, to the extent of the inconsistency, of no force and effect." In section 52(2), the Constitution of Canada is defined to include the Charter of Rights and Freedoms.

Section 52(1) authorizes the courts to declare legislation invalid on the basis of its inconsistency with the Constitution. It would appear that the discretionary standing rules as developed by the Supreme Court of Canada in the cases of Thorson, ${ }^{29} M c N e i l,{ }^{30}$ and Borowski $i^{31}$ will apply to applications under section 52(1). Section 52 contains no statutory standing provision, unlike section $24(1)$.

A question arises as to whether the application process set out in section 24(1) for Charter violations is self-contained. In other words, if one claims that legislation is invalid because it violates a section of the Charter of Rights and Freedoms, must that application be brought under section 24(1), thereby necessitating compliance with the stricter standing requirements of the section or could the application be made under section 52(1) of the Constitution Act, 1982 ? $^{32}$ Clearly, someone like Mr. Borowski does not have standing to make an application under section 24(1) ${ }^{33}$ However, under the common law rules of standing, as developed by the Supreme Court of Canada, he would have standing to seek a declaration of invalidity under section 52(1). The issue boils down to whether or not when seeking a declaration of invalidity, an applicant has an option to proceed under either section 52(1) or section 24(1). Clearly, when seeking any other remedy for a Charter violation, the applicant will have to meet the standing requirements of section 24(1). It should be noted that in many of the Charter decisions to date the courts have assumed that one of the remedies they may grant under section $24(1)$ is a declaration of invalidity. ${ }^{34}$

29. Thorson v. Attorney General of Canada (No. 2) [1975] 1 S.C.R. 138.

30. Nova Scotia Board of Censors v. McNeil [1976] 2 S.C.R. 265.

31. Supra n. 21.

32. For example, Ewaschuk, Q.C. General Counsel (Criminal Law) Department of Justice, Ottawa, makes the argument for treating s. 24(1) as a self-contained enforcement provision to deal with all alleged Charter infringements. See "The Charter: An Overview and Remedies" (1982) 26 C.R. (3d) 54 at 67.

33. Supra at 209-10. No personal right or freedom of Mr. Borowski has been infringed. He is not pregnant, nor is he likely to be. It is not alleged that he is the father of an unborn foetus threatened with abortion; nor is he a doctor or nurse who might be requested to perform such an operation.

34. See, for example, The Queen and G.B., a Juvenile v. Edmonton Journal, supra n. 19 in which the Edmonton Journal brought an application under both s. 24(1) and s. 52(1), for, inter alia, a declaration that s. 12(1) of the Juvenile Delinquents Act was inconsistent with the Charter. Dea J. made the following comments, at 2 of the judgment:

In an application under s. 24(1), the applicant must be a person whose rights or freedoms, as guaranteed by the Charter, have been infringed or denied. An application under s. 52(1) on the other hand need not disclose that kind of personal injury. Section 52(1) authorizes an appropriate declaration wherever the legislation being questioned is inconsistent with the Charter.

See also Quebec Association of Protestant School Boards, supra n. 26 at 39.41. 
If section 24(1) is a self-contained and exclusive procedure which must be used for any application concerning an alleged Charter violation, a situation might arise in which someone like Mr. Borowski would have standing under section 52(1) to contest the constitutional validity of section 251(4), (5) and (6) of the Criminal Code on the basis of section 1(b) of the Bill of Rights, but who would be unable to challenge the validity of the subsections on the basis of section 7 of the Charter of Rights and Freedoms due to the lack of standing.

In summary, it is unlikely that section $24(1)$ will be interpreted as the exclusive procedure through which Charter questions can reach the courts. Section 52(1) is an alternative process by which Charter questions may be determined, when the remedy sought is a declaration of invalidity. ${ }^{35}$

\section{Notice Requirements}

Another issue in relation to the making of a Charter application is whether notice must be given to the Attorneys-General of Alberta and Canada in accordance with section 25(1) of the Judicature Act, R.S.A. 1980, C. J-1. The subsection reads:

If in a proceeding the constitutional validity of an enactment of the Parliament of Canada or of the Legislature of Alberta is brought into question, the enactment shall not be held to be invalid unless fourteen (14) days written notice has been given to the Attorney-General for Canada and the Attorney.General for Alberta.

If the remedy being sought is a declaration of invalidity, an application under either section 52(1) or section 24(1) will require notice to be given to both the provincial and federal Attorneys-General. Any decision on validity will deal directly with the definition and scope of the legislative powers of both the provincial legislatures and the federal Parliament. Therefore, they have a direct and immediate interest in being informed of such an application and in having the opportunity to appear. ${ }^{36}$ This concern was

35. In The Queen and G.B., a Juvenile v. Edmonton Journal, supra n. 19, Dea J. after finding the Journal had no right personal to it infringed so as to give it standing under s. 24(1), decided the newspaper had standing to seek a declaration under s. 52(1). He stated at 11 of the judgment:

While it is true that Southam, Inc. is not an interested person in the juvenile trial, it is, I think a "concerned citizen" questioning an interpretation of the constitutional document and ought to be accorded standing for the purpose of bringing the matter before the Court for determination. (Minister of Justice of Canada v. Borowski 130 D.L.R. (3d) 588.).

Dea J. does not seem to consider the third element of the test set out by Martland J. in Borowski which requires the court to determine whether there is any other reasonable and effective manner in which the issue may be brought before the court. It is possible a juvenile or his family might argue that the juvenile's right to a fair and public hearing as granted in s. 11(d) of the Charter has been violated by section 12(1) of the Juvenile Delinquents Act. If this is a reasonably likely scenario, then it is suggested, on the basis of the Borowski test, the Edmonton Journal should not have been granted standing.

36. Russell v. The Queen (1882) 7 App. Cas. 829 (J.C.P.C.) provides an excellent example of an important and controversial decision being rendered by the Privy Council without the benefit of hearing representations from any of the provincial or the federal Attorneys-General. The judgment of the Privy Council dealt with the interpretation of the opening words of s. 91, "peace, order and good government". Barry L. Strayer, in his book, Judicial Review of Legislation in Canada (1968) at 40 states that there was "some subsequent feeling that the decision might have been otherwise had one or more of the provinces been heard". He also notes, at 41 , that it was shortly after this decision that statutory procedures were introduced "to ensure that the appropriate attorneys-gen. eral would be notified of, and permitted to appear in, constitutional litigation". 
put forward by the Attorney-General of Alberta in the case of Regina $\mathrm{v}$. Stanger. ${ }^{37}$ Madame Justice Veit summarized the arguments of the Attorney-General on the necessity for notice in the following terms: ${ }^{38}$

As I understand the position of the Crown, it is that the province has the constitutional right to enact such a requirement arising from: its responsibility for the administration of justice; its obligations relating to the prosecution of criminal matters; and also its interest in this area, as there are reverse onus sections in the Criminal Code which it administers and there may be reverse onus sections in provincial statutes.

Nowhere in the Constitution Act, 1867, or the Constitution Act, 1982, is there any constitutional requirement for notice to be given to the appropriate attorneys-general. Therefore, this procedural limitation is not authorized by the supreme law of the land.

It is important to distinguish between applications in which the constitutional validity of an enactment is being challenged and those applications, which must be brought under section 24(1), where validity is not the issue but where a particular application of a statute or common law rule is being challenged or where the conduct of an official, such as a policeman, is being challenged as having violated the applicant's rights. On the terms of section 25(1) of the Judicature Act, notice is only required where the validity of an enactment is in issue.

The case law dealing with the necessity for notice is conflicting. In Regina v. Stanger, ${ }^{39}$ Madame Justice Veit determined that notice was not required under section 25(1) of the Judicature Act. However, she decided the defendant was not raising a question of invalidity, but rather was asking the court to apply the standards of the Charter to the interpretation of section 8 of the Narcotic Control Act. ${ }^{40}$ This application was under section 24(1). However, comments made by Madame Justice Veit, in the course of her judgment, indicate that she would not require notice under section 52(1) of the Constitution Act, 1982. She stated:41

... each province could make access to the Charter rights dependant on different circumstances, which seem to me to be against the spirit of the Canadian Constitution. Along that line, it seems to me that s. 52(1) of the Constitution Act, 1982, which declares that the constitution of Canada is the supreme law of the land does not accord well with the submission that notice must be given to invoke the supreme law of Canada. Surely, a supreme law ought to be able to be invoked without special notice.

In the case of Re Koumoudouros and Municipality of Metropolitan Toronto, ${ }^{42}$ an attack was launched on a municipal by-law. The attack was two-fold: first, on the operability of the by-law as it effected the applicant;

37. (1983) 70 C.C.C. (2d) 247.

38. Id. at 248.

39. Supran. 37.

40. This statement by Veit J. at 247 seems to indicate she was asked to "read down" s. 8 of the Narcotics Control Act. If this is the case, it is suggested the reading down of the statute does involve an issue of constitutional validity, as the term is used in s. 25(1) of the Judicature Act. When a court "reads down" a statute, it has concluded that certain circumstances or events to which the words of the legislation could apply are beyond the legislative competence of the enacting authority. In so deciding, the court is considering and defining the scope of the legislative power(s) being challenged. In addition, if a court decides it cannot "read down" the enactment, then it will have to decide whether it is intra vires as it stands. Also, see the comments of the Alberta Court of Appeal in Broddy, infra, n. 43.

41. Supran. 37 at 249.

42. (1982) 67 C.C.C. (2d) 193 (Ont. H.C.). 
and second, on the validity of the provision of the Municipal Act which empowered the Municipality to pass the by-law being challenged. On a preliminary motion as to whether notice should be served under section 35(1) of the Judicature Act, ${ }^{43} \mathrm{Mr}$. Justice Catzman ordered notice of the substantive application be given to the Attorneys-General. ${ }^{44}$

43. Judicature Act, R.S.O. 1980 , c. 223 , s. 35(1).

44. Other cases dealing with the requirement of notice are: (1) Regina v. Leggo (1983) 69 C.C.C. (2d) 443, a decision of Dinkel P.C.J., Provincial Court of Alberta, in which he determined notice under s. 25 of the Judicature Act was not required where the application was based on s. 24(1) of the Charter. It should be noted the issue before him was not one of the validity of the legislation but whether an accused had been denied his rights to be tried within a reasonable time; (2) Regina v. B.S., an unreported decision of Vogelsong P.C.J., Provincial Court of Ontario(Family Division), dated May 26, 1982, in which Vogelsong P.C.J. declined to deal with an application made on behalf of a newspaper to be admitted into a juvenile proceeding because the application dealt with a question of invalidity under s. 11(d) of the Charter; (3) Broddy v. The Director of Vital Statistics [1983] 1 W.W.R. 481, a decision of the Alberta Court of Appeal, in which the applicants argued that they had been deprived of their liberty to marry, a right granted by section 7 of the Charter of Rights and Freedoms, due to the effect of section 57(1) of the Child Welfare Act, R.S.A. 1980, c. C-8. Kerans J.A. said the following in relation to notice at 492:

... this issue is not properly before us. There is nothing to indicate that written notice in this regard had been given to the Attorney-General for Canada or the Attorney-General for Alberta. In my view, a proposal to read down in light of the Charter is also an attack on validity, and s. 25(1) of the Judicature Act, R.S.A. 1980 c. J-1, applies. The practice of this Court is to require strict adherence to these provisions. Accordingly, I will not deal with the Charter issue.

45. In support of this view are the comments of Barry L. Strayer in his book Judicial Review of Legislation in Canada (1968) at 47.48:

A question remains whether these requirements of notice to the attorney-general can be reconciled with general principles of judicial review. When properly applied, notice requirements can act as a bar to an adjudication by a court on the constitutional validity of a statute involved in proceedings before it. If one takes an absolute approach to judicial review, and argues that the courts must always be entitled to review because they are "superior courts" or because they must apply the "whole law", or because they are operating in a federal system, such limitations on adjudication should be held invalid. It is submitted, however, that such an approach is unjustified. These procedural limitations are a legitimate exercise of the grant of power to the provinces to create and regulate the jurisdiction of their courts, at least in proceedings involving substantive questions within the provincial sphere. This is the power which justifies the provincial requirements of notice to the attorney general as a condition precedent to constitutional adjudication. Similarly, Parliament in the exercise of its jurisdiction over federal courts and the criminal law, and incidentally to the regulation of other federal matters, could introduce similar restrictions in any proceedings in federal courts or brought under federal law.

Notice requirements are not colourable devices essentially directed to the prevention of judicial review. The practical effect of these requirements must surely be to facilitate rather than to hamper the functioning of a federal system. They do not operate as an absolute bar to adjudication, but merely create conditions precedent with which it is not difficult to comply. They ensure that the appropriate governments have an opportunity to be represented so that the constitutional issues may be thoroughly canvassed by those having a continuing concern and interest with respect to the validity of legislation. The desirability of notice to the attorney general has been judicially recognized even where not strictly required by statute. The notice procedure has advantages over a system where constitutional decisions with far-reaching consequence may be made in litigation between private parties, sometimes in share-holders' or other similar actions where the conf lict between the parties is more apparent than real. Although the notice requirements may on occasion limit the right of judicial review, they thereby achieve the fundamental objective of making the courts effective agents in the operation and supervision of the federal structure. [Footnotes omitted.] 
In summary, it seems likely that notice will be required under section 25(1) of the Judicature Act, when the validity of an enactment is challenged, although no such procedural limitation on a person's right to make an application is mandated under either section 24(1) of the Charter or section 52(1) of the Constitution Act, 1982. The importance of notice to the federal and the appropriate provincial attorneys-general is unquestioned when an issue of validity is raised. The definition and scope of their legislative powers will be analyzed and called into question. The long-term effects of such a decision on both provincial and federal legislative jurisdiction could conceivably be drastic, but in all cases, will be of sufficient importance to justify notice being served on the appropriate attorneysgeneral to ensure all relevant issues are canvassed and presented for a court's consideration. ${ }^{45}$

\section{C. "MAY APPLY"}

It is unlikely that a judge will require a separate formal application to raise a Charter issue where the issue arises during the course of other proceedings, for example, during the course of a criminal trial. Support for this view is found in the decision of Regina v. Peters, where Her Honour Judge Wedge said: ${ }^{46}$

Formal notices of motion in provincial courts hearing cases under Part XXIV are almost unknown. I am satisfied that, in keeping with less technical summary conviction proceedings and the spirit of the law of the Charter, informal applications under $\mathbf{s} .24$ may be made in this court before or during the trial, or after all of the evidence has been heard, which ever is appropriate for the remedy being sought.

Since section 24(1) states that only someone whose rights and freedoms have been infringed may make an application, it is unlikely that a judge is entitled to take a point under the Charter ex mero motu and grant a remedy even though there has been no application by the person whose rights have been violated. However, the comments of His Honour Judge M. Charles in the case of Regina v. MacDonald are of interest on this point. He stated: ${ }^{47}$

It has been suggested in certain quarters that s. 24 of the Charter of Rights and Freedoms prohibits a judge suo motu from impugning any legislation which infringes, abrogates or denies the rights and freedoms guaranteed by the said Charter ... In such circumstances can it be argued that, unless an accused or a defendant, whose rights or freedoms as guaranteed by the Charter have been infringed or denied by a federal or provincial Act has raised the issue, a court is precluded from impugning the validity of the relevant Act. Such a view is untenable and felacious because if it is accepted by a court the court would be committing an elementary error in law relating to its jurisdiction.

It is suggested that, as a matter of practicality, if a judge believes there is evidence of a Charter violation, he will suggest to counsel they might like to consider such a point and present argument upon it.

\section{D. "TO A COURT ${ }^{48}$ OF COMPETENT JURISDICTION"}

Like so many others in the Charter, this phrase has not been defined.

46. An unreported decision of Wedge P.C.J., Provincial Court of Saskatchewan (Judicial Center of Saskatoon), dated June 28, 1982.

47. An unreported decision of M. Charles P.C.J., Provincial Court (Criminal Decision), Judicial District of Waterloo, dated July 15, 1982.

48. Quaere, whether the word "tribunal" in the French version of s. 24(1) includes administrative boards as well as courts. See Gibson, supra n. 28 at 501. 
Therefore, the question arises as to what is a court of competent jurisdiction for the purposes of an application under section 24(1).

Debate seems to have centered on two possible theories: one, that a court of competent jurisdiction is one seized with jurisdiction over the subject matter and the parties; and two, that it is one not only seized with jurisdiction over the subject matter and the parties, but also over the remedy being sought..$^{49}$

The most often quoted definition of what constitutes a court of competent jurisdiction is that of Collins M.R., in the case of Regina v. Garrett where he stated: ${ }^{30}$

... it is said the use of the words "a Court of competent jurisdiction" implies that there is a special provision made for recovery before a particular Court and to the exclusion of every other Court

... the expression "Court of competent jurisdiction" seems to me to be only a compendious expression covering every possible court which, by enactment, is made competent to entertain a claim for the recovery of paving expenses.

It is suggested that this definition is not particularly helpful since the Charter does not define those courts which are competent to entertain claims in relation to alleged Charter violations. It is likely that the phrase "court of competent jurisdiction" was not defined because the drafters intended such a court to be one which, independently of the Charter, was seized with jurisdiction over the "claim"; i.e., the subject matter, the parties and the remedy.

If this approach is followed, difficult issues such as whether courts of criminal jurisdiction can grant civil remedies for a Charter violation are avoided. However, this interpretation may not be in accord with the words,

49. Professor Hogg, in a recent book entitled Canada Act, 1982 Annotated, expresses the view that a Court can be competent to entertain an application under s. 24(1) if it has jurisdiction over the subject matter in issue and the parties thereto. He goes on to state at 65:

However, a Court which is competent as to subject matter and parties is probably not confined to remedies which are within its usual jurisdiction; the section itself confers the authority to grant an appropriate remedy.

Professor Dale Gibson in his article entitled "Enforcement of the Canadian Charter of Rights and Freedoms", supra n. 28, states that while competence as to remedy is important, a different interpretation of s. 24(1) may be possible. He states at 502:

It will be noted that s. 24(1) deals separately with the questions of "competent jurisdiction" and "remedy". After directing complainants to a court of competent jurisdiction, the section then empowers the court to provide "such remedy as the Court considers appropriate and just in the circumstances". Although this could be construed to refer only to remedies within the court's normal competence, it would have been easy for the drafters of the section to say so expressly: they did not. It is therefore open to the courts to find that the term "court of competent jurisdiction" refers only to jurisdiction over subject matter and parties, every court having been given unlimited discretionary competence over remedies by the concluding words of the section.

50. [1907] 1 K.B. 881 at $885-886$ (C.A.). Collins M.R. was considering an assertion that a metropolitan police magistrate was not "a court of competent jurisdiction" within the meaning of s. 3 of the Metropolis Management Amendment Act, 1890, 53 and 54 Vict., c. 66 , for the purpose of ordering recovery by the Borough Council of expenses for repairs done by the Council on a carriage road. It is suggested Collins M.R. did not intend to articulate a general definition of the phrase "court of competent jurisdiction." The phrase appeared in the challenged section before him and on the construction of the section, and the Act as a whole, he determined the phrase referred to those courts which, elsewhere in the legislation, had been given jurisdiction to hear claims in relation to the recovery of such expenses. 
however ambiguous, in section 24(1). The section declares that anyone may apply to a court of competent jurisdiction to obtain such remedy as the court considers appropriate and just in the circumstances. The words may be interpreted to mean that, so long as the court before whom the Charter issue is being argued, has jurisdiction over the subject matter and the parties, the court can grant any remedy it considers appropriate and just, whether or not it is a remedy the court would normally have jurisdiction to grant. ${ }^{51}$

A number of cases have considered the question of what constitutes a court of competent jurisdiction for the purposes of an application under section 24(1). In the case of Re Koumourdous and Municipality of Metropolitan Toronto, Mr. Justice Catzman of the Ontario High Court commented: ${ }^{.2}$

In the absence of specific legislative direction, the determination of the appropriate forum and the requirement of notice will depend upon an assessment of the nature and circumstances of the issues raised by, and the relief sought, upon the substantive application.

Mr. Justice Catzman concluded that the substantive determination was one calling for judicial review within the contemplation of section 2(1) of the Judicial Review Procedure Act, ${ }^{53}$ and that such an application must be made to the Divisional Court and not to a single judge of the High Court.

In the case of Regina v. Lyons (No. 2), ${ }^{54} \mathrm{Mr}$. Justice Seaton of the British Columbia Court of Appeal concluded that the Court of Appeal was not a court of competent jurisdiction under section 24(1) for the purpose of appointing counsel for a woman convicted of conspiring to traffic in narcotics. The woman had launched an appeal to the Supreme Court of Canada and Legal Aid refused to pay the cost of counsel. Mr. Justice Seaton stated: ${ }^{55}$

Because this case is not now before this court there is no ancillary jurisdiction to deal with this matter. Because it is statutory court it does not have the inherent jurisdiction in the sense $I$ am using that term.

My view is that the Court of Appeal for British Columbia is not the court, or one of the courts referred to in $\mathrm{s} .24$ of the Charter for the purposes of this case.

In the cases in the Supreme Court of Canada, as this one now is, and not in this court, I do not see how this Court can be described as a court of competent jurisdiction.

Mr. Justice Eberle of the Ontario High Court has decided that the Ontario Supreme Court is not a court of competent jurisdiction to quash an order of the Immigration Appeal Board. ${ }^{56}$ The applicant in the case not only applied for an order quashing the deportation order, but for an order of stay of execution and an order of habeas corpus. Mr. Justice Eberle, in

51. See n. 49, supra, for the views of Professors Gibson and Hogg on this point of interpretation.

52. Supra n. 42 at 197.

53. R.S.O. 1980 , c. 224.

54. (1982) 70 C.C.C. (2d) 1.

55. Id. at 2-3.

56. In the Matter of the Immigration Act, 1976, and In the Matter of the Execution of a Deportation Order Made on February 8, 1981 against Robert Joseph Gittens, a decision of Eberle J. of the Ontario High Court, dated April 17, 1982. 
accepting the argument of the respondent that the Supreme Court of Ontario had no jurisdiction in such matters stated: ${ }^{57}$

Immigration tribunals fall under the jurisdiction of the Federal Court. I agree that the Federal Court has sole jurisdiction over proceedings and decisions of the immigration tribunal and that the Supreme Court of Ontario has none."

He did however determine that the Supreme Court of Ontario had the jurisdiction to entertain an application for an order for habeas corpus. ${ }^{58}$ However, on the facts of the case, he felt that the detention was not unlawful and in fact the deportation order was justified and unassailable.

The approach the courts are taking in defining the phrase "a court of competent jurisdiction" is unremarkable, and certainly in accord with the various courts' previous statutory or inherent jurisdictions. ${ }^{59}$ This is not surprising since it is unlikely the courts would be willing to use the somewhat ambiguous words of section 24(1) to upset the recognized jurisdictions, statutory or inherent, of Canadian courts. One can predict that the courts will continue to operate on the basis that criminal remedies should be sought before criminal courts and civil remedies before duly constituted civil courts. It is suggested that any other approach will cause a multiplicity of problems in the administration of justice.

For example, if a provincial court judge, properly constituted as a court of criminal jurisdiction, were to receive an application alleging a Charter violation during a criminal trial and the applicant sought as remedies both the exclusion of evidence and civil damages against the Crown, it is clear the exclusion of evidence is a remedy within the judge's jurisdiction to grant. However, if the judge were to entertain the application for civil damages, he probably would have to conduct a separate trial on that issue. Clearly, the Crown would wish to discover defence witnesses and to present evidence of its own, not only on the question of liability but also, on the question of quantum of damages. The provincial court, constituted as a court of criminal jurisdiction is not, it is suggested, the appropriate forum for what is, in essence, a trial on the question of civil liability. Consequently, a provincial court judge in this situation should direct defence

57. Id. at 1.

58. An application was subsequently made in the Federal Court, Trial Division. (See Re Gitten and the Queen (1982) 68 C.C.C. (2d) 439.) Mahoney J. determined, at 442, that the Federal Court Trial Division was not a court of competent jurisdiction for the purpose of granting habeas corpus. Counsel will be well advised to peruse carefully the Federal Court Act, R.S.C. 1970, c. 10 (2nd. Supp.), as am., when making an application involving the government of Canada or its agencies. As well, when dealing with the provincial government and its agencies, legislation such as the Proceedings Against The Crown Act, R.S.A. 1980, c. P-18, should be considered. For example, s.10 states "Nothing in this Act authorizes proceedings against the Crown under Part IV of the Provincial Court Act or the Master and Servants Act".

59. But see, for a different view, the judgment of Allen P.C.J. in Regina v. Belton (1982) 69 C.C.C. (2d) 542, where he seems to adopt the position, apparently put forth by Crown Counsel, that "a court of competent jurisdiction" is one which has jurisdiction over the "substantive matter". Judge Allen goes on to state at 549:

As to the relief that may be given, it appears that the Charter has granted a very wide range within which a court can exercise its discretion. It may in the words of the Charter grant any relief "the court considers appropriate and just in the circumstances". I am satisfied therefore that if the accused is denied trial within a reasonable time, I can grant some form of relief.

Allen P.C.J. granted a stay of proceedings because of the unexplained delay in executing the warrant for the arrest of the accused. 
counsel to seek damages by making an application pursuant to section 24(1) to the Court of Queen's Bench or the Provincial Court, Small Claims Division, if appropriate. ${ }^{60}$

If, however, the criminal proceedings took place in the Court of Queen's Bench, a different result might follow. Although the Court of Queen's Bench, for the purposes of the criminal proceeding, would be constituted as a court of criminal jurisdiction, the Court does have the inherent jurisdiction to hear all claims, unless statutorily prohibited from doing so. Therefore, it is possible the Court would entertain the application for damages and no separate application would be necessary.

E. "TO OBTAIN SUCH REMEDY AS THE COURT CONSIDERS APPROPRIATE AND JUST IN THE CIRCUMSTANCES"

Some commentators have suggested that this phrase authorizes a court to grant any remedy it wishes as long as it is appropriate and just in the circumstances. ${ }^{61}$ As suggested above, the better and more likely interpretation of this clause is that it authorizes the court, before whom an application is made, to grant any remedy normally within the jurisdiction of that court. ${ }^{62}$ Therefore, a provincial court, for example, will not have vastly increased remedial powers. The intent of this phrase, it is suggested, was to make it plain that an applicant is not restricted to the remedial possibilities of "declarations and injunctions or similar relief". ${ }^{63}$ The effect of this phrase on the Court of Queen's Bench, which has inherent jurisdiction to grant any remedy unless statutorily prohibited, may be to encourage creativity in the fashioning of orders to deal with Charter violations. For example, the Court of Queen's Bench may use the final phrase of section 24(1) to develop remedies such as "the civil rights injunction" which has been used frequently by the United States Supreme

60. There has been some discussion as to whether an applicant is restricted to making one application in relation to an alleged violation of his rights. Section $24(1)$ states that "a person may apply to $a$ court of competent jurisdiction" (emphasis added). It seems unlikely this expression will be interpreted to preclude the possibility of a second application to a different court for a different remedy in relation to the same alleged violation. For example, to a provincial court of criminal jurisdiction for a stay and to a court of civil jurisdiction for damages.

61. Supra n. 49.

62. In support of this view, see the comments of Robert E. Lee P.C.J. in Regina v. Blackstock (1983) 29 C.R. (3d) 249, where he said at 254:

Under subsection 1 . . . the Court has the discretionary power to grant, in addition to the exclusion, whatever remedy the Court considers "appropriate and just in the circumstances". The remedy referred to must be a remedy that the particular court of competent jurisdiction has already as an inherent power or one given by statute. In the case of this court the first and most useful and final remedy that would come to mind would be to order a stay of proceedings. I wouldn't think, for example, that the court could direct a verdict of dismissal since that would necessarily involve determination on the facts and could only be done after the Court had considered the evidence remaining after the exclusion of the tainted evidence. Nor do I think the Court is empowered by ss. 1 to order the making of an apology, the payment of damages, or the performance of some act to draw attention to the transgression of the accused's rights.

63. These were the only remedial possibilities available to an applicant in Bill C.60, proposed in 1978. 
Court, especially in the area of desegregation. ${ }^{64}$

Remedies which one can expect to see granted by the appropriate court under section 24(1) include: injunctions, declarations, damages, prerogative remedies such as mandamus, certoriari, prohibition and habeas corpus, stays of proceedings, costs, acquittals and exclusion of evidence.

There has been some discussion as to whether section 24(1) may give rise to what is, in essence, a new tort action on the basis of a violation of a right guaranteed by the Charter. ${ }^{65}$ Certainly one of the remedies available to a superior court under section 24(1) will be damages. However, the remedy as with all remedies under the section, is discretionary. Damages will only be awarded in a situation where a court considers it appropriate and just to do so. ${ }^{66}$

From a perusal of decided cases to date, it appears the most common remedies sought by counsel are the exclusion of evidence, ${ }^{67}$ a stay of

64. See, for an in depth discussion of the civil rights injunction, O.M. Fiss, The Civil Rights Injunction (1978). It should be cautioned that s. 17 of the Proceedings Against The Crown Act, R.S.A. 1980, c. P.18, arguably limits the jurisdiction of the court to grant an injunction or specific performance against the Crown. See Professor Dale Gibson's comments, supra n. 28 , where he states at 507 :

A strong case can be made, however, for the proposition that the Crown's immunity to injunctions is not applicable where Charter violations are involved. The Charter is a constitutional document, superior in status to all ordinary laws, and the Courts have held, in other contexts that a government cannot clothe itself with immunity from judicial scrutiny of the constitutionality of its actions.

Even if this argument is mistaken, and the Crown's immunity from injunctive relief extends to Charter violations, there can be no doubt about the Crown's susceptibility to declaratory judgments and in most circumstances a judicial declaration that a governmental agency had acted unconstitutionally would, for practical purposes, be as helpful to the wronged individual as an injunction.

65. See generally Board of Governors of Seneca College of Applied Arts and Technology v. Bhadauria (1981) 124 D.L.R. (3d) 193 (S.C.C.).

66. As well, if by virtue of $s .32$, the Charter applies only to government action, damages could only be awarded where the Charter violation was due to such action. This would severely limit the scope of a "tort of discrimination".

67. See, for example, Re Potma and The Queen (1983) 67 C.C.C. (2d) 19, and Regina v. Siegel (1983) 29 C.R. (3d) 81. For discussion of the inter-relationship of s. 24(1) and s. 24(2), see infra at 234 et seq. 
proceedings, ${ }^{68}$ and a declaration of invalidity. One thing that has become plain from the early cases is that Canadian courts are very reluctant to encourage the development of what are, in effect, pre-trial supression hearings. Judges have ruled that a request for exclusion of evidence should be made at the time the evidence is tendered, either at the preliminary inquiry or at trial; there should be no encouragement of pre-trial motions requesting exclusion of evidence ${ }^{69}$ Therefore, if exclusion is sought before the evidence is tendered it is possible the court will decide that exclusion is not an appropriate and just remedy in the circumstances.

Clearly, whether a requested remedy is appropriate and just in the circumstances will depend upon a number of factors; for example, the substantive right violated, the extent or duration of the violation, the willfulness or vindictiveness on the part of the violators, and in a criminal case, the seriousness of the offence with which the applicant is charged.

In conclusion, it must be stressed that the granting of any remedy is a matter of discretion for the judge before whom the application is made. The judge may choose to grant no remedy in the circumstances or may choose to fashion a new remedy, at least in those circumstances where he has the jurisdiction to do so.

\section{SECTION 32 - APPLICATION}

Section 32(1) of the Charter states:

(1) This Charter applies:

(a) to the Parliament and government of Canada ...; and

(b) to the legislature and government of each province ...

The major question to be addressed in relation to the application of the Charter of Rights and Freedoms is whether the Charter applies only to "government action" or whether it also applies to "private action."

68. Lee P.C.J. in Regina v. Blackstock, supra n. 62, makes the following observations concerning when a court should entertain an application for a stay of proceedings at 254-255:

The making of an order for a stay of proceedings being a discretionary power, it shouldn't be directed as a matter of course every time an enforcement officer makes a mistake during an investigation that has the result of infringing upon the rights of the subject. If this became the practice of the courts, the public would quickly come to the conclusion that the Charter of Rights was absurd and probably lose confidence in the Courts as well. Surely it was never intended by the drafters of the Charter that an oversight mistake or slip of the tongue on the part of a law enforcement official would result, for all practical purposes, in a pardon for a criminal act.

Then Lee P.C.J. set out five circumstances in which he thought a stay of proceedings would be an appropriate and just remedy.

1. The act which deprived the accused of his or her right was done maliciously and/or with the intention of depriving the accused of the right.

2. In some way the accused has been prejudiced in either presenting his defence or in obtaining a fair hearing.

3. The infringement of the right cannot be remedied by only the exclusion of the tainted evidence.

4. The infringement of the right was done by an act or brings about a result that would cause the further prosecution of the defence to appear to be either scandalous to the public or cause the administration of justice to appear in an unfavourable light.

5 . The offence allegedly committed is of a minor nature.

69. For further discussion on this point, see infra at 239 et seq. 
Generally, a fundamental constitutional document, such as the Charter, is enacted to protect an individual against the possibility of government abuse. Protection of the individual from acts of discrimination by another individual is normally left to human rights legislation which now exists in all provinces and at the federal level. ${ }^{70}$ However, the words of section 32 do not exclude the possibility of applying the Charter's provisions to private conduct. In fact, it might be argued that the intention of the drafters of section 32 was merely to prevent the argument being raised that the Charter does not apply to government action. It is a basic tenet of statutory interpretation that unless legislative provisions are stated as binding upon the Crown, the presumption is that they are not. ${ }^{71}$

Notwithstanding this, it is suggested that the better view is that the Charter applies only to government action. To hold otherwise would increase the scope and ramifications of the Charter immeasureably. In fact, it would create an entirely new area of civil liability. Every time an individual discriminates against another on a prohibited basis under the Charter, the possibility of seeking damages for such action exists under section 24(1). As well, an application under section 24(1) of the Charter may not be the best method of resolving private disputes. The special dispute-resolution mechanisms now found in human rights legislation provides a more efficient method by which an individual could seek redress for an alleged violation of his rights by another individual. Settlement of a dispute out of court, either through informal meetings of the parties and a representative of a human rights commission or through a decision of a board of inquiry appointed under human rights legislation, often will be the least acrimonious method by which the dispute can be resolved. A formal application under section 24(1) of the charter will probably result in a heightening of tension and animosity between the parties. One of the main objectives of a human rights commission is, in fact, to resolve disputes through mechanisms which minimize these attendant problems.

Consequently, the Charter should not apply to private actions, per $s e$, $^{72}$ such matters being better left to those bodies specifically created to deal with such complaints. The very broad and general pronouncements of rights in the Charter is not the appropriate tool to resolve very specific allegations of discrimination which arise when one individual is accused of discriminating against another.

If it is concluded that the Charter does not apply to private action per se, one is still left with the problem of defining the scope of the concept of

70. For example, see Individuals Rights Protection Act, R.S.A. 1980, c. I-2, and Canadian Human Rights Act, S.C. 1976-77, c. 33.

71. For example, see the Interpretation Act, R.S.A. 1980, c. I-7, s. 14, which states:

No enactment is binding on Her Majesty or Her Majesty's rights or prerogatives in any manner, unless the enactment expressly states that it binds Her Majesty.

72. But see the comments of Dea J. in The Queen and G.B., a Juvenile v. Edmonton Journal, supra $\mathrm{n} .19$, where he states a contrary opinion at 6-7:

... Put simply the American Constitution protects the rights of citizens against government interference, whereas the Canadian constitution protects the rights of citizens against any interference, be it government or private. Because of that difference in concept the contest in Canada may be as in the U.S., i.e. between government and citizen or it may be quite different, i.e. between citizen and citizen 
"government action". Clearly, the concept includes the legislative actions of either a provincial legislature or the federal Parliament. As well, the concept should include any persons or bodies exercising statutory authority. Professor Peter Hogg expresses this idea in the following terms: ${ }^{73}$

. . any body exercising statutory authority, for example, a Governor-in-Council or Lieutenant-
Governor-in-Council, ministers, officials, municipalities, school boards, universities, admin-
istrative tribunals and police officers, is also bound by the Charter. Action taken under statutory
authority is valid only if it is within the scope of that authority. Since neither Parliament nor a
Legislature can itself pass a law in breach of the Charter, neither body can authorize action which
would be in breach of the Charter. Thus, the limitations on statutory authority which are
imposed by the Charter will flow down the chain of statutory authority and apply to regulations,
by-laws, orders, decisions, and all other action (whether legislative, administrative or judicial)
which depends for its validity on statutory authority. That is the way in which limitations on
statutory authority imposed by ss. 91 and 92 of the B.N.A. Act (and other distribution-of-powers
rules) work. There is no reason to treat limitations on statutory authority imposed by the Charter
any differently.

While it seems reasonably clear that the concept of "government action" will catch any person or body exercising statutory authority, what of persons or bodies not exercising such authority but arguably connected with government or performing what can be described as public functions? American jurisprudence in this area may be helpful in understanding the different approaches that the courts might take to this complex issue. ${ }^{74}$ Professor Gerald Gunther describes in the following terms, the two main tests used in the United States to determine whether action which allegedly violates the Bill of Rights comes within the concept of "state action":75

... most of the cases are preoccupied with the search for adequate elements of the "state". That search for indicia of state action follows two distinguishable routes. One may be called the "nexus" approach: it seeks to identify sufficient points of contact between the private actor and the state to justify imposing constitutional restraints on the private actor or commanding state disentanglement. That approach is exemplified by Burton v. Wilmington Parking Authority... which states "that private conduct abridging individual rights does no violence to the Equal Protection Clause unless to some significant extent the State in any of its manifestations has been found to have become involved in it." That search for "significant state involvements" permeates most of the cases - and raises numerous problems. The Burton approach assumes that a genuinely neutral state tolerance of private discrimination is permissible. But how much active, affirmative engagement by the state is necessary under that approach? Is it enough that the state "authorize" the private discrimination? Can authorization be distinguished from mere tolerance, where the state has power to forbid private discrimination and does not exercise that power? What varieties of more active state involvement satisfy the state action requirement? Must the state be shown to approve discrimination? To encourage discrimination? Is it enough that the state confers some benefits on the private discriminator? Must there be special benefits, such as a grant of a monopoly? Is state regulation of the discriminator enough? State licensing? State leasing or sale of property? Is it enough that the stated judicial system enforces the private discriminator's wishes, as part of a general system of property and contract law? Questions such as these are characteristic of the "significant state involvements" approach.

73. Supra n. 49 at 75. Courts also appear to be included within the concept of government. Traditionally, they are viewed as the third branch of government along with the legislative and executive branches. As well, most courts are of statutory creation. Finally, certain sections of the Charter would be deprived of meaning if the court were not included within the application thereof. For example, section 11 (d) guarantees to a person charged with an offence the right to ... "a fair and public hearing by an independent and impartial tribunal." Clearly, this right has no substantive content if the courts, who might deprive an individual of a fair and public hearing are not subject to the terms of the Charter.

74. See, for example, Lawrence H. Tribe, American Constitutional Law (1978) Chap. 18, and Gerald Gunther, Constitutional Law - Cases and Materials (1980) Chap. 11, at 978.1028.

75. Gunther, id. at 986.987 . 
The alternative to that "nexus" analysis is the "public function" approach. Instead of searching for formal contacts between the state and the private discriminator, it focuses on the nature of the activity the private discriminator engages in. Marsh v. Alabama, the company town case which follows, illustrates that approach. Basically, the "public function" analysis treats private enterprises whose "operation is essentially a public function" as sufficiently state-like to be treated as a state for purposes of applying constitutional guarantees. This was one of the earliest, most amorphous, and potentially most far-reaching themes in the expansion of the state action concept, but the cases of the 1970's have curtailed it sharply.

Clearly the adoption of tests such as these would greatly expand the application of the Charter. It is suggested our courts will be reluctant to define the word "government" so broadly, especially in light of the fact there is human rights legislation in all provinces which would catch the discriminatory acts and practices of, for example, businesses who operate under government licenses or regulation. It is more likely our courts will look to the body of existing law defining the Crown to develop a definition of "government" for the purposes of section $32 .{ }^{76}$

\section{ANALYSIS OF SECTION 24(2): THE EXCLUSION OF EVIDENCE}

For convenience let us restate section 24(2). It reads as follows:

Where in proceedings under subsection (1), a court concludes that evidence was obtained in a manner that infringed or denied any rights or freedoms guaranteed by this Charter, the evidence shall be excluded if it is established that, having regard to all the circumstances, the admission of it in the proceedings would bring the administration of justice into disrepute.

This section of the Charter deals with the admissibility (or more correctly, the exclusion) of evidence which has been obtained by an infringement or denial of a right or freedom guaranteed by the Charter.

\section{A. THE LAW IN CANADA}

The law in Canada has always been that evidence which is relevant is admissible no matter how it is obtained. Any notions to the contrary were laid to rest in Regina v. Wray ${ }^{77}$. In this case, the Crown tendered certain pieces of evidence obtained as a result of an involuntary confession. The trial Judge excluded this evidence. The Ontario Court of Appeal upheld the trial Judge's ruling. In a judgment delivered orally, Mr. Justice Aylesworth stated: ${ }^{78}$

In our view, a trial Judge has a discretion to reject evidence, even of substantial weight, if he considers that its admission would be unjust or unfair to the accused or calculated to bring the administration of justice into disrepute, the exercise of such discretion, of course, to depend upon the particular facts before him. Cases where to admit certain evidence would be calculated to bring the administration of justice into disrepute will be rare, but we think the discretion of a trial Judge extends to such cases.

Upon further appeal to the Supreme Court of Canada, this ruling was overturned and a new trial ordered. The majority ${ }^{79}$ held that there was no discretion in the trial Judge to exclude otherwise admissible evidence on the basis that it was obtained by illegal or improper means or in a manner tending to bring the administration of justice into disrepute. In reaching this decision, Mr. Justice Martland, writing for the majority, relied heav-

76. See Hogg, Liability of the Crown (1971), ch. 8.

77. Supra n. 12.

78. [1970] 3 C.C.C. 122 at 123.

79. Martland J., Fauteux, Pigeon, Judson, Ritchie and Abbott JJ. concurring; Cartwright C.J.C., Hall and Spence JJ. dissenting. 
ily upon the case of Kuruma, Son of Kaniu v. The Queen ${ }^{80}$. He adopted ${ }^{81}$ the test of admissibility enunciated by Lord Godard C.J. in Kuruma. ${ }^{82}$

In their Lordship's opinion the test to be applied in considering whether evidence is admissible is whether it is relevant to the matters in issue. If it is, it is admissible and the Court is not concerned with how the evidence was obtained.

However, Mr. Justice Martland did recognize ${ }^{83}$ the dictum of Lord Godard C.J. that: ${ }^{84}$

In a criminal case the judge always has a discretion to disallow evidence if the strict rules of admissibility would operate unfairly against the accused.

Mr. Justice Martland interpreted this dictum to mean that the residual discretion of the trial Judge was to exclude evidence where the prejudicial effect of the evidence outweighed its probative value. He stated: ${ }^{85}$

The exercise of a discretion of that kind is a part of the function of the Court to insure the accused has a fair trial. But other than that, in my opinion, under our law, the function of the Court is to determine the issue before it, on the evidence admissible in law, and it does not extend to the exclusion of admissible evidence for any other reason.

After a thorough review of the authorities ${ }^{86}, \mathrm{Mr}$. Justice Martland delivered the now famous statement that: ${ }^{87}$

The exercise of a discretion by the trial Judge arises only if the admission of the evidence would operate unfairly. The allowance of admissible evidence relevant to the issue before the Court and of substantial probative value may operate unfortunately for the accused but not unfairly. It is only the allowance of evidence gravely prejudicial to the accused, the admissibility of which is tenuous, and whose probative force in relation to the main issue before the Court is trifling, which can be said to operate unfairly.

It is readily apparent from this statement that the method of procuring evidence (i.e., whether it is obtained by illegal or improper means) plays no part in the determination of when a trial Judge should exercise his discretion to exclude otherwise admissible evidence.

The Wray decision was applied to the Canadian Bill of Rights in the case of Hogan v. The Queen ${ }^{88}$. In this case, the accused, who had been taken to the police station for breathalyzer tests, asked to speak with his lawyer prior to taking the test. The police officer refused to allow the accused to speak to his counsel even though the lawyer, who had been summoned to the police station by the accused's girlfriend, could be heard in an adjoining room. The police officer demanded that the accused blow into the breathalyzer or face the charge of failing or refusing to provide a sample of

80. [1955] A.C. 197.

81. Supra n. 12 at 287.

82. Supra n. 80 at 203.

83. Supran. 11 at 288.

84. Supra n. 80 at 204. It is interesting to note that Lord Godard goes on to state: "If, for instance, some admissions of some piece of evidence, e.g. a document, had been obtained from the defendant by a trick no doubt a judge might properly rule it out." This part is not quoted by Martland $\mathrm{J}$.

85. Supra n. 12 at 288.

86. Included in the discussion of authorities by Martland J. are the following cases: Noor Mohamed v. The King [1949] A.C. 182; Harris v. D.P.P. [1952] A.C. 694; Thompson v. The King [1918] A.C. 221; Callis v. Gunn [1946] 1 Q.B. 495; R. v. Court [1962] Crim. L.Rev. 697; R. v. Payne [1963] 1 W.L.R. 637; R. v. Murphy [1965] N.I. 138; King v. The Queen [1968] 2 All E.R. 610 and Rumping v. D.P.P. [1962] C.A.R. 397.

87. Supra n. 12 at 293.

88. Supra n. 7. 
one's breath for analysis. ${ }^{89}$ Faced with this alternative, the accused complied and registered a result of $230 \mathrm{mg}$ of alcohol per $100 \mathrm{ml}$ of blood. Quite naturally he was charged with driving a motor vehicle having consumed alcohol in a quantity such that the proportion of alcohol in his blood exceeded $80 \mathrm{mg}$ per $100 \mathrm{ml}$ of blood. ${ }^{90}$ The accused was convicted of the offence and his appeal to the Appeal Division of the Supreme Court of Nova Scotia ${ }^{91}$ was denied. His further appeal to the Supreme Court of Canada was essentially based upon the thesis that because he had been denied his right to counsel under section 2(c)(ii) of the Canadian Bill of Rights $^{92}$, his conviction for a violation of section 236(1) of the Criminal Code should be quashed. ${ }^{93}$ In rejecting the accused's argument and upholding the conviction, Mr. Justice Ritchie, speaking for the majority, ${ }^{94}$ stated: ${ }^{95}$

Whatever view may be taken of the constitutional impact of the Canadian Bill of Rights, and with all respect for those who may have a different opinion, I cannot agree that, wherever there has been a breach of one of the provisions of that Bill, it justifies the adoption of the rule of "absolute exclusion" on the American model which is in derogation of the common law rule accepted in this country.

Mr. Justice Laskin (as he then was) took the opposite position in dissent: ${ }^{96}$

The Canadian Bill of Rights is a half-way house between a purely common law regime and a constitutional one; it may aptly be described as a quasi-constitutional instrument. It does not embody any sanctions for the enforcement of its terms but it must be the function of the Courts to provide them in light of the judicial view of the impact of that enactment . . . It is to me entirely consistent, and appropriate, that the prosecution in the present case should not be permitted to invoke the special evidentiary provisions of s. 237 of the Criminal Code when they have been resorted to after denial of access to counsel in violation of s. 2(c)(ii) of the Canadian Bill of Rights. There being no doubt as to such denial and violation, the Courts must apply a sanction. We would not be justified in simply ignoring the breach of a declared fundamental right in letting it go merely with words of reprobation. Moreover, so far as denial of access to counsel is concerned, I see no practical alternative to a rule of exclusion if any serious view at all is to be taken, as I think it should be, of this breach of the Canadian Bill of Rights.

89. Criminal Code, s. 235(2).

90. Criminal Code, s. 236(1).

91. (1972) 5 N.S.R. (2d) 73.

92. Section 2(c)(ii) of the Canadian Bill of Rights provides:

Every law of Canada shall, unless it is expressly declared by an act of the Parliament of Canada that it shall operate notwithstanding the Canadian Bill of Rights, be so construed and applied as not to abrogate abridge or infringe or to authorize the abrogation, abridgement or infringement of any of the rights or freedoms herein recognized and declared, and in particular, no law of Canada shall be construed or applied so as to...

(c) deprive a person who has been arrested or detained ...

(ii) of the right to retain and instruct counsel without delay.

93. The accused's thesis was based upon the case of Brownridge v. The Queen [1972] S.C.R. 926, 7 C.C.C. (2d) 417. In this case, the accused refused to blow into the breathalyzer until he spoke to his counsel. Consequently, he was charged with refusal under s. 235(2) of the Criminal Code. He was acquitted essentially because he had been denied his right to counsel. The majority of the Supreme Court of Canada in Hogan distinguished Brownridge on the basis that the request to speak to counsel (and the denial of the request) provided a "reasonable excuse" (as per the wording of s. 235(2)) for refusing to blow into the breathalyzer. No such words, however, are present in s. 236(1) of the Criminal Code.

94. Ritchie J., Fauteux C.J.C., Abbott, Martland, Judson, and Dickson JJ.; Laskin J. and Spence J. dissenting. Pigeon J. wrote a separate short opinion concurring with Ritchie J.

95. Supra n. 7 at 582 .

96. Id. at 597-598. 
The decision in Regina v. Wray ${ }^{97}$ has attracted much attention and considerable criticism. ${ }^{98}$ Even prior to the Wray decision, the Ouimet Committee favoured a discretion in the trial Judge to exclude evidence which was illegally obtained. The Committee went further to suggest guidelines for the exercise of the discretion: ${ }^{99}$

(1) The Court may in its discretion reject evidence which has been illegally obtained.

(2) The Court in exercising its discretion to either reject or admit evidence which has been illegally obtained shall take into consideration the following factors:

(i) whether the violation of rights was wilful, or whether it occurred as a result of inadvertance, mistake, ignorance or error in judgment.

(ii) Whether there existed a situation of urgency in order to prevent the destruction or loss of evidence or other circumstance which in the particular case justified the action taken.

(iii) Whether the admission of the evidence in question would be unfair to the accused.

The Law Reform Commission of Canada also recommended the enactment of a provision in its Proposed Evidence Code to counteract the restrictiveness of the Wray decision. Section 15(1) of the Proposed Evidence Code provided: ${ }^{100}$

Evidence shall be excluded if it was obtained under such circumstances that its use in the proceedings would tend to bring the administration of justice into disrepute.

The Commission went further to suggest guidelines for the exercise of the discretion. Section 15(2) provides for these guidelines: ${ }^{101}$

In determining whether evidence should be excluded under this section all the circumstances surrounding the proceedings and the manner in which the evidence was obtained shall be considered, including the extent to which human dignity and social values were breached in obtaining the evidence, the seriousness of the case, the importance of the evidence, whether any harm to an accused of others was inflicted wilfully or not, and whether there were circumstances justifying the action, such as a situation of urgency requiring action to prevent destruction or loss of evidence.

Further, the Ontario Law Reform Commission saw the need to give power to the Court to refuse to admit into evidence anything obtained by illegal means. Among their recommendations was the following: ${ }^{102}$

A rule should be adopted with respect to illegally obtained evidence which would empower the Courts to refuse to admit in evidence anything which has been obtained by illegal means. This power should be a controlled power, to be exercised after considering all the material facts, the nature of the illegality and the concept of fairness to the parties involved.

In consequence of this recommendation, section 27 of their Draft Evidence Act provided as follows: ${ }^{103}$

In a proceeding where it is shown that anything tendered in evidence was obtained by illegal means, the Court, after considering the nature of the illegality and all the circumstances under which the thing tendered was obtained, may refuse to admit it in evidence if the Court is of the opinion that because of the nature of the illegal means by which it was obtained its admission would be unfair to the party against whom it is tendered.

97. Supran. 12.

98. Weinberg, "The Judicial Discretion to Exclude Relevant Evidence" (1975) 21 McGill L.J. 1; Gibson, "Illegally Obtained Evidence" (1973) U. of T. Fac. L.R. 23; Sheppard, "Restricting the Discretion to Exclude Admissible Evidence", (1972) 14 Crim. L. Q. 334; Heydon "Illegally Obtained Evidence" [1973] Crim. L.R. 603, 690, are but a few.

99. Report of the Canadian Committee on Corrections (Ouimet Committee Report)(1969) at 74.

100. Law Reform Commission of Canada, Report on Evidence (1975) at 122.

101. Id.

102. Ontario Law Reform Commission, Report on the Law of Evidence (1976) at 72.

103. Id. at 258. 
The Commission then went on to discuss the problem of evidence procured by methods repugnant to the fair administration of justice. ${ }^{104}$ After an exhaustive discussion of the Wray decision, the Commission concluded: ${ }^{105}$

In our view, the principles relied on in the dissenting judgments of the Supreme Court of Canada and in the judgment of the Court of Appeal should be used as a guide for remedial legislation. . . . We think trial Judges should have control over the admission of evidence so as to preserve the integrity of the judicial process and protect the administration of justice from practices likely to bring it into disrepute. The judicial process is not confined to the Court; it also encompasses officers of the law and others whose duties are necessary to ensure that the Courts function effectively.

Acting upon their conclusions, the Commission recommended that the Draft Evidence Act include the following provision: ${ }^{106}$

26. In a proceeding the court may refuse to admit evidence that otherwise would be admissible if the court finds that it was obtained by methods that are repugnant to the fair administration of justice and likely to bring administration of justice into disrepute.

The McDonald Royal Commission also recommended a statutory judicial discretion to exclude illegally obtained evidence. ${ }^{107}$

The Federal/Provincial Task Force on Uniform Rules of Evidence took the opposite approach. A majority of the Task Force recommended: ${ }^{108}$

that legislation not be enacted to authorize the exclusion of evidence obtained illegally, improperly or by means likely to bring the administration of justice into disrepute.

In consequence of this recommendation, section 22 of the Uniform Evidence Act provides: ${ }^{109}$

(1) Relevant evidence is admissible unless it is excluded pursuant to this Act or any other Act or law, and evidence that is not relevant is not admissible.

(2) The Court may exclude evidence the admissibility of which is tenuous, the probative force of which is trifling in relation to the main issue and the admission of which would be gravely prejudicial to a party.

It should be noted that subsection (2), if enacted, would give legislative approval to the holding of Mr. Justice Martland in the Wray decision. ${ }^{110}$ Bill S-33, The Canada Evidence Act, 1982 proposes only a slight alteration in this provision to take account of the Charter: ${ }^{11}$

22(1) Relevant evidence is admissible unless it is excluded pursuant to the Canadian Charter of Rights and Freedoms, this Act or any other Act or law, and evidence that is not relevant is not admissible.

(2) The court may exclude evidence the admissibility of which is tenuous, the probative force of which is trifling in relation to the main issue and the admission of which would be gravely prejudicial to a party.

104. Id., Chapter 5, 73-94.

105. Id at 94 .

106. Id. at 258.

107. Freedom and Security Under the Law (The Second Report) at 1045.

108. The Federal/Provincial Task Force on Uniform Rules of Evidence, Report on Evidence (1982) at 233. It should be noted here that the members of the Task Force were by and large members of various governments involved in the project and in many instances, crown prosecutors. There were no official representatives of the criminal defense bar as such.

109. Id. at 549 .

110. Supra n. 87 and accompanying text.

111. Bill S-33, An Act to give effect for Canada to the Uniform Evidence Act Adopted by the Uniform Conference of Canada (First Reading November 18, 1982). See also Institute of Law Research and Reform, Evidence and Related Subjects: Specific Proposals for Alberta Legislation (Report No. 37B) at 91. 
Subsection (2) of the proposed Bill S-33 remains the same as in the Uniform Evidence Act.

In conclusion, it must be noted that none of the proposals for reform mentioned above has been legislatively enacted. The pre-Charter law in Canada remains that enunciated by Mr. Justice Martland in Wray.

\section{B. THE LAW IN OTHER COMMONWEALTH COUNTRIES}

In spite of some contradictory decisions, ${ }^{12}$ the ratio of Kuruma v. The Queen ${ }^{113}$ appears, to represent the present day law in England. This was affirmed in the case of Regina v. Sang ${ }^{114}$. In this case, the accused was charged with conspiring with others to utter forged United States banknotes. Before the trial began, counsel for the defendant requested a voir dire be held. He hoped to show that the defendant's conduct was the product of entrapment. Once that was proved, the defendant's counsel hoped to convince the trial Judge to exercise his discretion to exclude evidence of the commission of the offence and, consequently, direct a verdict of not guilty. The trial judge, without holding the voir dire, ruled that he had no discretion to exclude evidence of this kind even if it had been obtained by entrapment. The defendant then changed his plea to one of guilty and was sentenced to serve 18 months imprisonment. The defendant's appeal to the Court of Appeal, Criminal Division, ${ }^{115}$ was denied. However, the Court certified that the following point of law was of general public importance and was involved in the decision: ${ }^{116}$

Whether, a trial judge has discretion to refuse to allow evidence, being evidence other than evidence of admission, to be given in any circumstances in which such evidence is relevant and of more than minimal probative value.

The House of Lords granted leave to appeal. ${ }^{117}$ The House of Lords, with some of their Lordship's disagreeing on the reasonings, unanimously dismissed the appeal. In commenting on the Kuruma decision and the statement of Lord Godard C.J. as to the trial judge's discretion to exclude evidence, ${ }^{118}$ Lord Diplock stated: ${ }^{119}$

That statement was not, in my view, ever intended to acknowledge the existence of any wider discretion than to exclude (1) admissible evidence which would probably have a prejudicial influence on the minds of the jury that would be out of proportion to its true evidential value and (2) evidence tantamount to a self-incriminatory admission which was obtained from the Defen. dant, after the offence had been committed, by means which would justify a judge in excluding an actual confession which had the like self-incriminating effect.

112. In particular, $R$. v. Payne, supra n. 86; $R$. v. Court, supra n. 86; $R$. v. Murphy, supra n. 86; $R$. v. Ameer and Lucas [1977] Crim. L. Rev. 104.

113. Supra n. 80.

114. [1979] 2 All E.R. 1222 (H.L.).

115. [1979] 2 All E.R. 46.

116. Id. at 64 .

117. Although Lord Salmon stated ". . this is a strange appeal which plainly has no hope of succeeding", supra n. 113 at 1235.

118. Supra n. 84 and accompanying text.

119. Supra $\mathrm{n}$. 114 at 1229-30. It should be noted that the second prong of Lord Diplock's test for the exercise of discretion, seems to add a new wrinkle to the test in Kuruma. Further, this second aspect to a trial judge's discretion casts more doubt on the correctness of Martland J.'s decision in Wray. Indeed, Lord Diplock goes on to state: "There is no discretion to exclude evidence discovered as the result of an illegal search but there is discretion to exclude evidence which the accused has been induced to produce voluntarily if the method of inducement is unfair." Arguably this would cover the Wray situation. Supra n. 114 at 1230. 


\section{Lord Diplock, then, discussed the role of the trial judge in the following terms: ${ }^{120}$}

The function of the judge at a criminal trial as respects the admission of evidence is to ensure that the accused has a fair trial according to law. It is no part of a judge's function to exercise disciplinary powers over the police or prosecution as respects the way in which evidence to be used at the trial is obtained by them. If it was obtained illegally there will be a remedy in civil law; if it was obtained legally but in breach of the rules of conduct for the police, this is a matter for the appropriate disciplinary authority to deal with. What the judge at the trial is concerned with is not how the evidence sought to be adduced by the prosecution has been obtained but with how it is used by the prosecution at the trial. . . . However much the judge may dislike the way in which a particular piece of evidence was obtained before proceedings were commenced, if it is admissible evidence probative of the accused's guilt it is no part of his judicial function to exclude it for this reason.

Other Commonwealth countries provided the trial judge with a much broader discretion to exclude illegally obtained evidence than is found in either Kuruma v. The Queen or Regina v. Sang. For example, in the Scottish case of Lawrie v. Muir ${ }^{121}$, evidence obtained by an illegal search of premises was excluded by a decision of the Full Bench of the High Court of Justiciary. The evidence was not only relevant to the offence charged, but highly probative of the accused's guilt. In discussing the competing values presented by the issue of the admissibility of illegally obtained evidence, the Lord Justice-General stated:122

From the stand point of principle it seems to me that the law must strive to reconcile two highly important interests which are liable to come into conflict - (a) the interest of the citizen to be protected from illegal or irregular invasions of his liberties by the authorities, and (b) the interest of the State to secure that evidence bearing upon the commission of crime and necessary to enable justice to be done shall not be withheld from Courts of law on a merely formal or technical ground. Neither of these objects can be insisted upon to the uttermost. The protection of the citizen is primarily protection for the innocent citizen against unwarranted, wrongful and perhaps high-handed interference, and the common sanction is an action in damages. The protection is not intended as a protection for the guilty citizen against the efforts of the public prosecutor to vindicate the law. On the other hand the interest of the State cannot be magnified to the point of causing all the safeguards for the protection of the citizen to vanish, and of offering a positive inducement to the authorities to proceed by irregular methods. It is obvious that excessively rigid rules as to the exclusion of evidence bearing upon the commission of a crime might conceivably operate to the detriment and not the advantage of the accused, and might even lead to the conviction of the innocent; and extreme cases can easily be figured in which the exclusion of a vital piece of evidence from the knowledge of the jury because of some technical flaw in the conduct of the police would be an outrage upon common sense and a defiance of elementary justice.

The Lord Justice-General went on to state that there was no absolute rule and the matter was one of balancing the competing values in the circumstances of each case. He stated: ${ }^{123}$

Irregularities require to be excused, and infringements of the formalities of the law in relation to these matters are not lightly to be condoned. Whether any given irregularity ought to be excused depends upon the nature of the irregularity and the circumstances under which it was committed. In particular, the case may bring into play the discretionary principle of fairness to the accused which has been developed so fully in our law in relation to the admission in evidence of confessions or admissions by a person suspected or charged with crime. That principle would obviously require consideration in any case in which the departure from the strict procedure had been adopted deliberately with a view to securing the admission of evidence obtained by an unfair trick. . . . on the other hand, to take an extreme instance figured in argument, it would usually be wrong to exclude some highly incriminating production in a murder trial merely because it was found by a police officer in the course of a search authorized for a different purpose or before a proper warrant had been obtained.

120. Id.

121. [1950] S.L.T. 37.

122. Id. at $39 \cdot 40$.

123. Id. at 40 . 
This decision appears to be an application of the guidelines suggested by the Ouimet Committee ${ }^{124}$ and the Law Reform Commission of Canada. ${ }^{125}$

Other Scottish cases apply the principles set forth in Lawrie v. Muir. For example, in M'Govern v. H.M. Advocate, ${ }^{126}$ the High Court of Justiciary ruled inadmissible the evidence derived from the analysis of fingernail contents where the contents were obtained by improper means. On the other hand, in Fairley v. The Wardens of the City of London Fishmongers, ${ }^{127}$ the High Court of Justiciary ruled that evidence obtained from an illegal search was admissible. In H.M. Advocate v. Turnbull, ${ }^{128}$ Lord Guthrie ruled that certain documents obtained improperly were inadmissible. But, Lord Guthrie in H.M. Advocate v. Hepper ${ }^{129}$ ruled that an attaché case, the subject of a theft charge, was properly admitted into evidence even though it was irregularly obtained. H.M. Advocate v. McKay ${ }^{130}$ and Hay v. H.M. Advocate ${ }^{131}$ are two other cases in which the courts exercised their discretion under the principles enunciated in Lawrie v. Muir ${ }^{132}$ to admit evidence which was obtained by improper means.

The definitive case in Australia appears to be Regina v. Ireland. ${ }^{133}$ In that case an issue arose as to whether photographs of the accused's hand and subsequent medical testimony based upon the photographs were admissible where the photographs were obtained without the accused's consent. In holding that both the photographs and the medical testimony were inadmissible, Chief Justice Barwick, writing for the unanimous High Court, stated: ${ }^{134}$

Evidence of relevant facts or things ascertained or procured by means of unlawful or unfair acts is not, for that reason alone, inadmissible. . . On the other hand evidence of facts or things so ascertained or procured is not necessarily to be admitted, ignoring the unlawful or unfair quality of the acts by which the facts sought to be evidenced were ascertained or procured. Whenever such unlawfulness or unfairness appears, the judge has a discretion to reject the evidence. He must consider its exercise. In the exercise of it, the competing public requirements must be considered and weighed against each other. On the one hand there is the public need to bring to conviction those who commit criminal of fences. On the other hand there is the public interest in the protection of the individual from unlawful and unfair treatment. Convictions obtained by the aid of unlawful or unfair acts may be obtained at too high a price. Hence the judicial discretion.

In Bunning v. Cross, ${ }^{135}$ the High Court confirmed that the statements of Chief Justice Barwick in the Ireland case represented the law in Australia. In coming to this determination, the Court rejected the notion that the House of Lords decision in Kuruma $\mathrm{v}$. The Queen ${ }^{136}$ represented the law in Australia on this point. Justices Stephen and Aickin recognized that

124. Supra $\mathrm{n} .99$ and accompanying text.

125. Supra $\mathrm{n} .100$ and accompanying text.

126. [1950] S.L.T. 133.

127. [1951] S.L.T. 54.

128. [1951] S.L.T. 409.

129. [1958] S.L.T. 160.

130. [1960] S.L.T. 174.

131. [1968] S.L.T. 334.

132. Supra n. 121.

133. (1970) 126 C.L.R. 321.

134. Id. at 334-5.

135. (1978) 52 A.J.L.R. 561.

136. Supran. 80. 
"the statement of principle in Ireland's case differs from some statements of principle overseas." 137 They went on to state: ${ }^{138}$

There exists a marked contrast between, on the one hand, the approach manifest in Ireland's case and also in cases decided in the Irish and Scottish courts . . . And on the other hand, that of English and Canadian Courts and of their Lordships in the Judicial Committee ... As we understand it, the law in Australia now differs somewhat from that in England. What Lord Godard C.J., speaking for their Lordships, said in Kuruma's case, reflects the latter. Whatever may have initially been the authority of Ireland's case in the light of the earlier decision of their Lordships in Kuruma ... we have no hesitation in following the principles established in Ireland's case. . .

New Zealand, unlike Canada and Australia, has not abolished appeals to the Judicial Committee of the Privy Council. However, in the 1976 Court of Appeal case of Police v. Hall, ${ }^{139}$ the discretion to exclude improperly obtained evidence was exercised. In this case, involving a charge of impaired driving, a doctor had conducted a clinical examination of the accused and questioned him about the accident in which he had been involved as well as his drinking prior to the accident. This examination had taken place without the accused's consent. At trial, the doctor gave evidence that the accused could not properly have operated the motor vehicle at the time of the offence. In quashing the conviction, the Court of Appeal stated: $:^{140}$

We have referred to the need to avoid any unfairness by subjecting a person to a general medical examination without his consent. In this case the failure to obtain consent, particularly as the doctor described the Appellant as argumentative, taken together with other features of the case, leads us to think that what occurred was unsatisfactory. The other features are the refusal, for no reason, to allow this youthful Defendant to telephone for the advice of his father or his solicitor; the loss of a blood sample, and the possible influence upon the whole conduct of the prosecution of the practice already discussed. The cumulative effect of these matters is such that in our opinion, the doctor's evidence of his examination should have been excluded in the Court's discretion in the interest of fairness.

In Regina v. Pethig, ${ }^{141}$ the trial Judge's broad discretion to exclude improperly obtained evidence was exercised to rule inadmissible evidence of an undercover police officer regarding offences committed by the accused as a result of entrapment. ${ }^{142}$

In the Irish case of People v. O'Brien and O'Brien, ${ }^{143}$ the question of whether the trial Judge had a discretion to exclude otherwise admissible evidence, if it was obtained by illegal means, arose. Mr. Justice Kingsmill Moore, after canvassing numerous decisions from a variety of jurisdictions opted for a discretion similar to that described in Lawrie v. Muir, ${ }^{144}$ to exclude such evidence. He stated: ${ }^{145}$

It is desirable in the public interest that crime should be detected and punished. It is desirable that individuals should not be subjected to illegal or inquisitorial methods of investigation and that the State should not attempt to advance its ends by utilising the fruits of such methods. It appears to me that in every case a determination has to be made by the trial Judge as to whether the public interest is best served by the admission or by the exclusion of evidence of facts ascertained as a result of, and by means of, illegal actions, and that the answer to the question depends on a consideration of all the circumstances.

137. Supra n. 135 at 568 .

138. Id.

139. [1976] 2 N.Z.L.R. 678.

140. Id. at 684 .

141. [1977] 1 N.Z.L.R. 448.

142. Id. at 453 .

143. [1965] I.R. 142.

144. Supra n. 121.

145. Supra n. 143 at 160 . 
In People v. O'Laughlin, ${ }^{146}$ the Court of Criminal Appeal for Ireland held that the accused's statement, made during his illegal detention in violation of his constitutional rights, must be excluded from evidence. Chief Justice O'Higgins stated: ${ }^{147}$

Even on the basis of there having been a deliberate and conscious violation of constitutional rights, the trial Judge was prepared to exercise his discretion in favour of admitting this statement. He was prepared to do so because, in his view, it served the public interests in the circumstances. This Court cannot agree with that view. There are no circumstances in this case which can excuse what took place. It would ill serve respect for the Constitution and the laws of this Court, by allowing evidence so obtained, to indicate to citizens generally that the obligations on the State to safeguard and vindicate constitutional rights could be dispensed with or eased in the circumstances of a criminal investigation. For these reasons, this Court is of the opinion that the learned trial Judge erred in admitting as evidence the written statement made by the accused at the Garda Station in Clonmel.

From this perusal of the cases from other Commonwealth jurisdictions, two things become obvious. First, there is no doubt that the pre-Charter law in Canada provides a trial Judge with the narrowest scope for the exercise of his residual discretion to exclude evidence. Even the position in England, as delineated in Regina v. Sang, ${ }^{148}$ provides for a wider scope to the discretionary power of the trial Judge. ${ }^{149}$ Consequently, the Canadian approach has been the least protective of the rights of the individual. Second, it is apparent that the type of discretion envisioned by section 24(2) of the Charter is not a discretion which is unknown to common law judges with a judicial heritage similar to our own.

\section{A BRIEF NOTE ON THE AMERICAN EXCLUSIONARY RULE}

It is clear that no absolute rule of exclusion, such as exists in the United States, is contemplated by section 24(2) of the Charter. Consequently, the American jurisprudence on this topic will be but briefly noted. ${ }^{150}$ The American exclusionary rule is based upon the Fourth and Fifth Amendments to the American Bill of Rights. ${ }^{151}$ In 1914, in Weeks v. United States, ${ }^{152}$ the United States Supreme Court held that articles seized as a result of an illegal search were not admissible in evidence in a criminal

146. [1979] I.R. 85 .

147. Id. at 92 .

148. Supra n. 114.

149. See n. 119, supra, and accompanying text.

150. For a more detailed discussion of the United States position, see Whitebread, Criminal Procedure, (1980); Tribe, supra n. 74; Lockhart, Kamisar, and Choper, Constitutional Rights and Liberties (1970); Gunther, supra n. 74, and McCormick, Evidence (2nd ed., 1972).

151. The Fourth Amendment provides:

The right of people to be secure in their persons, houses, papers, and affects, against unreasonable searches and seizures shall not be violated, and no Warrants shall issue but upon probable cause, supported by Oath and Affirmation, particularly describing the place to be searched, and the person or things to be seized.

The Fifth Amendment provides:

No person shall be held to answer for a capital, or otherwise infamous crime, unless a presentment or indictment of a Grand Jury, excepting cases arising in the land or naval forces or in the Militia, when in actual service in time of War or public danger; nor shall any person be subject for the same offence to be twice put in jeopardy of life or limb; nor shall be compelled in any criminal case to be a witness against himself, nor be deprived of life, liberty, or property, without due process of law; nor shall private property be taken for public use, without just compensation.

152. 232 U.S. $383(1918)$. 
trial. Writing for the unanimous court, Mr. Justice Day reasoned: ${ }^{153}$

To sanction such proceedings would be to affirm by judicial decision a manifest neglect if not an open defiance of the prohibitions of the Constitution, intended for the protection of people against such unauthorized actions.

In the case of Silverthorne Lumber Co. v. United States ${ }^{154}$ the exclusionary rule in Weeks was expanded to include derivative evidence. This doctrine became known as "the fruit of the poisonous tree" doctrine. The rule is as follows: ${ }^{155}$

Evidence derived from information acquired by police officials through unlawful means is not admissible in a criminal prosecution.

The rationale behind the extension of the exclusionary rule to cover derivative evidence is stated in the Silverthorne case: ${ }^{156}$

The essence of a provision forbidding the acquisition of evidence in a certain way is that not merely evidence so acquired shall not be used before the Court but that it shall not be used at all.

In Nardone v. United States, ${ }^{157}$ the "fruit of the poisonous tree" doctrine was applied to evidence obtained as a result of information gained from an illegal wire tap. A refinement on the test of causal connection was introduced in Wong Sun v. United States. ${ }^{158}$

It should be noted, however, that certain doctrines have been developed which allow for the admission of "tainted" secondary evidence. ${ }^{159}$ These doctrines include the independent source doctrine, (i.e., evidence was procured other than by means of illegal acts ${ }^{160}$ and the doctrine of attenua. tion (i.e., the connection between the official illegality and the proferred evidence has become so "attenuated" or distant as to remove the taint from the evidence). ${ }^{161}$ This will often be the result of some act of free will on the part of the accused or a third party. The third doctrine constraining the derivative evidence rule is that of "inevitable discovery", (i.e., the derivative evidence would have been discovered by the police regardless of their acts in violation of the Constitution. $)^{162}$

In Wolfv. Colorado ${ }^{163}$ the Supreme Court of the United States refused to use the Fourteenth Amendement ${ }^{164}$ to apply the exclusionary rule to the

153. Id. at 394 .

154. 251 U.S. 385 (1920).

155. Whitebread, supra n. 150 at 30.

156. Supra n. 154 at 392.

157. 308 U.S. 338 (1939).

158. 371 U.S. 471 (1963).

159. Whitebread, supra $\mathrm{n}$. 150 at $33-37$.

160. U.S. v. Crews 445 U.S. 463,100 S. Ct. 1244 (1980).

161. Wong Sun v. U.S., supra n. 158, U.S. v. Seccolini 435 U.S. 268,98 S. Ct. 1054 (1978).

162. For example, see Somer v. U.S. 138 F. 2d 790 (1943); Wayne v. U.S. 318 F. 2d 205 (1963), cert. denied 375 U.S. 860,84 S. Ct. 125; U.S. v. Seohnheim 423 F. 2d 1051 (1970), cert. denied 399 U.S. 913, 90 S. Ct. 2215.

163. 338 U.S. 25 (1949).

164. The Fourteenth Amendment provides:

Section 1. All persons born or naturalized in the United States, and subject to the jurisdiction thereof, are citizens of the United States and of the State wherein they reside. No State shall make or enforce any law which shall abridge the privileges or immunities of citizens of the United States; nor shall any State deprive any person of life, liberty, or property, without due process of law; nor deny to any persons within this jurisdiction the equal protection of the laws... 
States. This decision was reversed in Mapp v. $\mathrm{Ohio}^{165}$ and the exclusionary was applied to the States. ${ }^{166}$

There have, however, been some qualifications on the "absolute" rule of exclusion. ${ }^{167}$ For example, a balancing approach is now taken whenever there is an attempt to apply the exclusionary rule to situations other than a criminal trial. By this test the court balances the deterrent effect of the rule's use in the particular situation against the cost to the government and society by the loss of the probative evidence. ${ }^{168}$

A second qualification on the rule of exclusion is the harmless error doctrine, which arises where the deprivation of the individual's constitutional right has not been prejudicial to the defendant's interest. For example, if the trial's outcome would have been the same even if the evidence had been excluded, the failure to apply the rule will not be fatal to the conviction. In particular, one should note Fahy v. Connecticut ${ }^{169}$ and Chapman v. California. ${ }^{170}$

Further, waiver of the constitutional right also provides a limitation on the operation of the exclusionary rule. The defendant will be deemed to have waived his right where he has made no attempt to suppress the evidence by pre-trial motion, ${ }^{171}$ taken no objection to the proferred evidence at trial, ${ }^{172}$ or when he offers the tainted evidence himself. ${ }^{173}$

Finally, there appears to be some movement towards a "good faith" exception to the absolute rule of exclusion. In the case of Michigan v. DeFillippo, ${ }^{174}$ the Supreme Court allowed evidence obtained as a result of a search following an unconstitutional arrest to be admitted because the police officers were operating on the basis of a presumptively valid statute. In Williams v. U.S. ${ }^{175}$ the Supreme Court denied certiorari on a decision of the 5th Circuit which adopted a "good faith" exception to the exclusionary rule. Most recently in an extraordinary decision, the Supreme Court restored the case of Illinois v. Gates ${ }^{176}$ to the calendar. The court ordered argument of the following question:

whether the rule requiring the exclusion at a criminal trial of evidence obtained in violation of the Fourth Amendment, Mapp v. Ohio, 367 U.S. 643 (1961); Weeks v. United States, 232 U.S. 383 (1914), should to any extent be modified, so as, for example, not to require the exclusion of evidence obtained in the reasonable belief that the search and seizure at issue was consistent with the Fourth Amendment.

165. 367 U.S. $643(1961)$.

166. See also, Ker v. California 374 U.S. 23 (1963). In Ker v. California, the Supreme Court of the United States ordered that federal standards regarding the lawfulness and reasonableness of an alleged unconstitutional search and seizure or arrest be used in determining whether the exclusionary rule should be applied.

167. See, generally, Whitebread, supra n. 150 at 18-30.

168. For example, see U.S. v. Calandra 414 U.S. 338 (1974); U.S. v. Janis 428 U.S. 433 (1976), and Stone v. Powell 428 U.S. 465 (1976), for cases in the U.S.S.C.

169. 375 U.S. $85(1963)$.

170. 386 U.S. $18(1967)$.

171. U.S. v. Mauro 507 F. 2d 802 (1974).

172. U.S. v. Wardens of Attica State Prison 381 F. 2d 209 (1967).

173. McCain v. State 363 S.W. $2 d 257$ (1963).

174. 443 U.S. 31 (1979).

175. 622 F. 2 d 830 (1980), cert. denied 449 U.S. 1127,101 S. Ct. 946 (1981)

176. 51 L.W. 3415 . 
In conclusion, the American exclusionary rule and the "fruit of the poisonous tree" doctrine appear to be highly effective in criminal trials at the present time, although certain attempts to limit the breadth of the rule are gaining momentum.

\section{THE MEANING OF SECTION 24(2)}

The precise meaning of section 24(2) of the Charter will be the subject of considerable debate and litigation. The meaning that will be conclusively attached to the words of the section is, at this time, a matter for speculation only. Nonetheless, it is clear that certain important issues are raised by the section. What follows canvasses some of these issues.

\section{Can Evidence be Excluded Under Both Section 24(1) and 24(2)?}

This question raises the issue of whether evidence may be excluded either because it is "appropriate and just in the circumstances" to do so, pursuant to section 24(1), or because it would "bring the administration of justice into disrepute", pursuant to section 24(2). The argument in favour of the position that evidence may be excluded on the basis of either section 24(1) or section 24(2) was made by His Honour Judge Muir in the case of Regina v. Therens. ${ }^{177}$ In this case, the defendant was charged with having consumed alcohol in such a quantity that the proportion thereof in his blood exceeded $80 \mathrm{mg}$ of alcohol per $100 \mathrm{ml}$ of blood, contrary to section 236(1) of the Criminal Code. This charge arose out of an accident involving the accused. A police officer, who arrived at the scene of the accident, demanded that the accused submit to a breathalyzer test. The accused complied with the demand. Samples of his breath were taken, analyzed, and a certificate was prepared. The accused was not informed of his right to retain and instruct counsel as provided for in section 10(b) of the Charter. At trial, the accused's counsel sought to have the results of the breathalyzer excluded because of the denial of his client's right under section 10(b). Contrary to the Crown's objection, His Honour Judge Muir concluded that the power to exclude evidence was not limited to cases falling under section 24(2) but might be exercised if it was a remedy "appropriate and just in the circumstances" under section 24(1). Judge Muir stated: ${ }^{178}$

I regard s. 24(2) not as limiting the provisions of s. 24(1) but rather as strengthening the enforcement mechanism by providing that, in the particular circumstances set forth in s. 24(2), the Court shall exclude the evidence.

In other words, under section 24(1) the Court has a discretion (i.e., the word "may") to exclude evidence if it is "appropriate and just in the circumstances" to do so, but has a positive duty (i.e., the word "shall") to exclude the evidence if the requirements of section 24(2) are met. Judge Muir went on to exclude the evidence of the analysis of the breathalyzer test as an "appropriate and just" remedy in the circumstances.

This theory propounded by Judge Muir would imply that upon application to exclude evidence, two tests of exclusion must be employed. First, if the requirements of section $24(2)$ are satisfied, the evidence must be excluded. If, however, the requirements of section 24(2) are not satisfied,

177. (1983) 70 C.C.C. (2d) 468. For an expression of a contrary view, without reasons, see Re Regina and Siegel, supra n. 67.

178. Id. at 472 . 
then the Court must still consider if it should exercise its discretion to exclude the evidence because it would be "appropriate and just in the circumstances" to do so. This is the second test.

It should be noted that no other case seems to have adopted this approach. In other cases, the courts have applied the test in section 24(2) but do not go on to consider the evidence in relation to the test provided in section 24(1). Judge Muir considered section 24(1) and, having decided to exclude the evidence on the basis that it was appropriate and just to do so, did not need to examine the evidence in light of section 24(2).

A contrary theory must be acknowledged. This theory proposes that the exclusion of evidence is a remedy available only through section $24(2){ }^{179}$ By this theory, certain words are impliedly added to the section so that the section would, in effect, read as follows: "Where in proceedings under subsection (1), where the remedy sought is the exclusion of evidence . ..". However, it must be noted that the latter clause (i.e., "where the remedy sought is the exclusion of evidence") is not part of the section. Further, there is no clause in either section 24(2) or in section 24(1) which expressly limits the court's power to grant remedial relief in the form of the exclusion of evidence.

There is, however, some support for this theory. Such support may be inferred from the opening phrase of section 24(2). The phrase, "where in proceedings under subsection (1)", may be given a number of interpretations. Indeed, it is more than a bit ambiguous.

The phrase "in proceedings under subsection (1)" is capable of a meaning which would make it applicable only when evidence obtained in violation of the Charter is abduced at a proceeding for a remedy under section 24(1). This interpretation places an unreasonable meaning on the phrase.

A more logical interpretation of this phrase is that subsection (2) has no independent life of its own but rather is called into play when there has been an application for a remedy pursuant to subsection (1) and the remedy sought is the exclusion of evidence. Put another way, the court, in determining if it is "appropriate and just in the circumstances" to exclude evidence, must employ that test stated in section 24(2). This, it should be recognized, produces the result that a discretionary power (i.e., the power under section 24(1)) to be exercised in broad terms, is transformed into a positive obligation (i.e., under section 24(2)) compelling the exclusion of evidence under much stricter terms.

Regardless of which theoretical position is ultimately adopted, it is unlikely that the different theories will produce different results. It would be curious for a court to find that the test under section 24(2) is not satisfied but that it is still "appropriate and just in the circumstances" to exclude the evidence. This is so because the test provided for in section $24(2)$ is in large part discretionary. The phrase "having regard to all the circumstances would bring the administration of justice into disrepute" implies a balancing between the rights of the individual to be free from violation of his constitutional rights and the duty of the state to prosecute

179. Re Regina and Siegel, supra n. 67 at 87 . Also such a theory is implied in Levy, "Procedural, Evidential and Remedial Aspects of the Canadian Charter of Rights: A Case Study of Section 8" (Unpublished paper); Ewaschuk, supra n. 32. 
crimes and gain convictions. The outcome of this balancing process will depend in large measure on how seriously the court views the particular constitutional violation or indeed how seriously the courts view constitutional rights generally. This discretion will manifest itself in the courts' determination of whether the admission of the evidence would bring the administration of justice into disrepute. Consequently, any difference based upon the presence of the words "may" in subsection (1) and "shall" in subsection (2) is illusory.

\section{When is it Appropriate to Apply for the Exclusion of Evidence?}

Generally speaking, it makes good sense to apply for exclusion of evidence at the time the evidence is tendered. However, at least two issues arise here. First, can an application be made to exclude evidence prior to the commencement of the proceedings? That is, can there be pre-trial suppression motions? The Charter does not explicitly deal with this issue but the better view appears to be that applications in the nature of pretrial suppression motions are not contemplated by the Charter and consequently, will most likely not be permitted, at least at the outset.

The very nature of the process envisioned by section 24(2) is the weighing and balancing of various circumstances in determining whether the admission of the impugned evidence would bring the administration of justice into disrepute. ${ }^{180}$ Whether there has been a denial or infringement of a right guaranteed by the Charter is only one question before the courts in an inquiry under section 24(2). The denial or infringement of the right must still be viewed in "all the circumstances" of the case (circumstances that would generally only become apparent during the trial) to determine whether the admission of the impugned evidence would bring the administration of justice into disrepute. To permit collateral or contingent applications to exclude evidence would result in two trials - one on the application to exclude evidence, the other on the guilt or innocence of the accused - with much the same evidence presented at both. The cost and delay involved make this an undesirable procedure. This has been the view taken in the majority of the early cases on the Charter. ${ }^{181}$

However, an argument might be advanced supporting the view that the Charter does permit pre-trial suppression motions. This argument finds its genesis in the opening phrase of section 24(2), namely "where in proceedings under subsection (1)". If it is correct, as was earlier argued, ${ }^{182}$ that subsection (2) is dependent upon subsection (1) (i.e., the exclusion of evidence is not a remedy available under both subsections), then the opening phrase in subsection (2) would appear to permit separate proceedings for the exclusion of evidence as a Charter remedy. This position is reinforced by the wording of section 24(1): "Anyone whose rights or freedoms, as guaranteed by this Charter, have been infringed or denied may apply to a court . ..". This clause supports the view that pre-trial suppression motions should be permitted.

A second issue raised here is whether a provincial court Judge may exercise the discretion under section 24(2) to exclude evidence at a prelimi-

180. See infra at 73 et seq.

181. For example, see Re Regina and Siegel, supra n. 67; Re Potma and the Queen, supra n. 67; Regina v. Imough (1982) 9 W.C.B. 106.

182. See discussion, supra at 238-239. 
nary hearing. It has been argued by one commentator that a provincial court Judge is not permitted to do so. ${ }^{183}$ This view seems to be based, in one respect, upon the notion that a preliminary hearing is not a trial but is preliminary to the trial. In this regard, it must be noted that the section refers to "proceedings", not just trials. Certainly a preliminary inquiry is a "proceeding" within the meaning of this term. Secondly, the use of evidence obtained in violation of the Charter at any judicial proceeding could bring the administration of justice into disrepute. Further, it is an integral part of the role of the provincial court Judge presiding at a preliminary hearing to rule on the admissibility of evidence. For example, the cases of Regina v. Pickett ${ }^{184}$ and Regina v. Norgren ${ }^{185}$ indicate that the confession rule applies at preliminary hearings. Other cases are to like effect. ${ }^{186}$

A second argument used to support the position that a provincial court Judge may not entertain an application to exclude evidence at a preliminary hearing rests upon the notion that at a preliminary hearing the provincial court Judge is acting as a persona designata and not as a "court" as provided in section $24(2) .{ }^{187}$ This is a highly technical interpretation of the word "court". Rather, constitutional documents should be given a wide and liberal interpretation. ${ }^{188}$ To place upon the word "court" the narrow construction suggested would unreasonably constrict the application of section 24(2).

Second, the decision of the Supreme Court of Canada in Herman v. Deputy A.G. Canada appears to strictly confine the term persona designata when used in reference to a judge. Mr. Justice Dickson stated: ${ }^{189}$

Prima facie, Parliament should be taken to intend a judge to act qua judge whenever, by statute, it grants powers to a judge. He who alleges that a judge is acting in the special capacity of a persona designata must find in the specific legislation provisions which clearly evidence a contrary intention on the part of Parliament. The test to be applied in considering whether such a contrary intention appears in the relevant statute can be cast in the form of a question: is the judge exercising a peculiar and distinct and exceptional jurisdiction, separate from and unrelated to the tasks which he performs from day to day as a judge and having nothing in common with the court of which he is a member?

This case concerned a judge appointed under section 96 of The Constitution Act, 1867. However, the tenor of the entire decision is one critical of the concept of persona designata.

183. Ewaschuk, supra n. 32.

184. (1976) 28 C.C.C. (2d) 297 (Ont. C.A.).

185. (1975) 27 C.C.C. (2d) 488 (B.C.C.A.).

186. Re Baptiste and the Queen (1982) 65 C.C.C. (2d) 510 (B.C.C.A.); Re Regina and Commisso et al No. 2 (1977) 35 C.C.C. (2d) 237 (B.C.S.C.); Re Regina and Jones (Nos. 1 and 2) (1974) 16 C.C.C.(2d) 338; Re Depagie and The Queen (1976)32 C.C.C.(2d) 89; Re Regina and Siegel, supra n. 67; Re Regina and Shea (1982) 8 W.C.B. 238.

187. See Doyle v. The Queen (1976) 35 C.R.N.S. 1 at 6 per Ritchie J.:" . . it is my opinion that the powers and functions of a magistrate acting under the Criminal Code are circum. scribed by the provisions of that statute and must be found to have been thereby conferred either expressly or by necessary implication."

188. Supran. 26.

189. (1979)5 C.R. (3d) 242 at 256. In a separate concurring judgment, Laskin C.J.C. accepted the following quote from D.M. Gordon, "Persona Designata"(1927)5 Can. Bar Rev. 174 at 185:" ". the whole persona designata conception could be scrapped without the least distortion of legal principles", (at 260). The Chief Justice went on to conclude: ". . I I think this court should declare that whenever a statutory power is conferred upon a judge or officer of a court, the power is deemed exercisable in his official capacity as representing the court unless there is express provision to the contrary." 
It appears that the better view is that an application to exclude evidence may be made (and indeed granted) during the preliminary hearing. This seems to be a reasonable position given the numerous options open to the Crown in this regard. First, to avoid a ruling excluding evidence they can disclose more of their case at the preliminary stage, thus showing circumstances which could lead the court to decide that the admission of the tendered evidence would not bring the administration of justice into disrepute. If the accused is committed for trial in spite of the exclusion of evidence, the Crown may attempt to adduce the impugned evidence again at trial if it feels the evidence is essential to gain a conviction. If, on the other hand, the accused is not committed for trial, the Crown may appeal the Court's ruling. Finally, the Crown may prefer an indictment under the provisions of section 507(3)(b) of the Criminal Code.

This range of options available to the Crown clearly indicates that the remedy in section 24(2), and for that matter, those in section 24(1), should be available to the accused at the preliminary hearing stage.

\section{3. "Where. . . A Court Concludes": Upon Whom is the Burden of Proof and What Standard Must be Met?}

The Charter does not provide for the allocation of burdens of proof when a remedy is sought for a violation of one of its substantive provisions. However, the phrase "where . . . a court concludes" in section 24(2) seems to place the burden of persuasion on the party asserting that the evidence was obtained in a manner that had violated the provisions of the Charter. Although section 24(1) is not so clear on this point, the phrase "whose rights or freedoms ... have been infringed or denied" strongly implies that prior to granting a remedy, the court must find that there has been a violation of the Charter. It is quite reasonable to assume that the party asserting the violation must prove it under section 24(1) as well.

An alternative theory is arguable. ${ }^{190}$ Under this theory, at least in criminal cases, a burden of production is placed upon the accused while the burden of persuasion rests upon the Crown. The basis for this theory, at least in relation to section 24(1), is that when an accused, seeking an acquittal or a stay, sets up a violation of the Charter in support of his application, he is raising a general defence to which the doctrine of reasonable doubt would apply. In other words, just as an accused has only an evidentiary burden (or a burden of production) to raise the defence of drunkenness, leaving the burden of persuasion on the issue to the Crown, so too when the accused has sufficiently raised the defence of, let us say, unreasonable delay (section 11(b) of the Charter), it is up to the Crown to negative that assertion beyond a reasonable doubt. This, of course, implies that the rights and freedoms guaranteed by the Charter add to the arsenal of general defences available to the accused. ${ }^{191}$

In terms of section 24(2), a similar argument is possible. It is well established that the party tendering a particular piece of evidence must prove any preliminary facts which condition that evidence's admissibility. For example, it is trite law that prior to a confession being admitted into evidence the Crown must prove that it was freely and voluntarily given. So

190. See Levy, supra n. 179.

191. It should be noted that a different result may flow when the remedy sought under $s$. 24(1) of the Charter is a civil remedy such as damages or an injunction, or so forth. 
too, it might be argued, that upon the accused raising the question of whether the evidence should be excluded because of the manner in which it was obtained, it would then fall to the Crown to prove that the evidence should not be excluded by the operation of section 24(2).

Although this is an ingenious argument, it seems to defy the plain meaning of section 24(2) and the probable meaning of section 24(1). It would appear that under section 24(1), the burden of persuasion is upon the applicant to establish that a right or freedom has been infringed or denied and that the remedy sought is appropriate and just in the circumstances. This the applicant must do on the balance of probabilities or the preponderance of evidence, which is the usual civil burden.

Under section 24(2), the burden of persuasion is upon the applicant to show that (1) a right or freedom has been infringed or denied, (2) there is a causal connection between the obtaining of the evidence and the denial or infringement of the right, and (3) the admission of evidence would bring the administration of justice into disrepute. The burden of persuasion on the last issue would appear to be upon the applicant because of the phrase "if it is established" as interpreted in the landmark case of Regina v. Appleby. ${ }^{192}$ Once again, all of these burdens must be satisfied on the balance of probabilities or the preponderance of evidence.

The question remains: upon whom is the burden to show the existence of "reasonable limits prescribed by law as can be demonstrably justified in a free and democratic society"? The answer to this question seems fairly clear: it is up to the government to show that there is some statute or regulation or rule of common law that prescribes a reasonable limitation and that such limitation is justified in a free and democratic society. As Dr. B.L. Strayer, Q.C., Assistant Deputy Minister of Justice, stated to the Joint Committee: ${ }^{193}$

Mr. Chairman, it was the belief of the drafters that by going to these words demonstrably justified or can be demonstrably justified, it was making it clear that the onus would be on the government or whoever is trying to justify the action limiting the rights set out in the Charter, the onus would be on them to show that the limit which was being imposed not only was reasonable which was in the first draft, but also that it was justifiable or justified, and in doing that they would have to show that in relation to the situation being dealt with, the limit was justifiable.

The standard of proof required in relation to section 1 is a matter of some debate. If the intention of Parliament was for the courts to employ the usual civil burden of the preponderance of evidence or balance of probabilities, it is doubtful that the phrase "demonstrably justified" would have been used. This phrase implies a heavier burden than "more justifiable than not". It would seem reasonable that the use of the term "demonstrably justified" implies proof which is clear and conclusive. However, in the case of The Federal Republic of Germany v. Rauca, Chief Justice Evans stated that he considered "the extent of that burden to be the usual civil onus based on the balance of probabilities". ${ }^{194}$ Nonetheless, Chief Justice Evans in discussing the government's onus under section 1 of

192. [1972] S.C.R. 303,3 C.C.C. (2d) 354.

193. Proceedings of the Joint Committee on the Constitution of Canada, supra n. 8, No. 38 at 45.

194. (1983) 30 C.R. (3d) 97. 
the Charter, stated that: ${ }^{195}$

The notion of justification is qualified by the word "demonstrably" which means in a way which admits of demonstration which in turn means capable of being shown or made evident or capable of being proved clearly and conclusively. The standard of persuasion to be applied by the Court is a high one if the limitation in issue is to be upheld as valid. [Emphasis added.]

And further Chief Justice Evans stated: ${ }^{196}$

Because the liberty of the subject is in issue I am of the view that the evidence in support must be clear and unequivocal. Any lesser standard would emasculate the individuals rights now enshrined in the Constitution. [Emphasis added.]

Although Chief Justice Evans' decision is unclear on this issue, the foregoing passages indicate that he would exact a very high degree of proof.

To illustrate the foregoing, a voir dire to exclude evidence obtained from the accused in violation of his rights under the Charter, for example, when he has been denied his right to counsel, might work something like this:

1. The burden of persuasion is upon the accused to show on the balance of probabilities that his right to retain and instruct counsel without delay and to be informed of that right has been infringed or denied. At this stage, the Crown might attempt to show that the right had not been infringed or denied.

If the Crown is successful in leaving the Judge in doubt on this issue, the accused's application must fail.

2. But, if the accused satisfies the Judge on the balance of probabilities that his right to retain and instruct counsel without delay and to be informed of that right, has been denied or infringed, the Crown then has the burden of satisfying the court that there is (a) a reasonable limitation upon the right, (b) that the limitation is prescribed by law, and (c) that it is justified in a free and democratic society. They must demonstrate this upon clear and conclusive evidence.

If the Crown satisfies their burden on this issue, the accused's application will be dismissed.

3. However, if the Crown fails to satisfy the burden under 2, the accused may go on to show (a) the causal connection between the obtaining of the evidence and the infringement or denial of the right and (b) that the admission of the evidence would bring the administration of justice into disrepute. Both of these "facts" must be proved on the balance of probabilities.

4. "Evidence Was Obtained in a Manner That Infringed or Denied the Right or Freedom Guaranteed by This Charter"

Two points should be made on this issue. First, not all cases involving illegally or improperly obtained evidence will support an application for the exclusion of evidence under section 24(2) or another remedy under section 24(1). It is only evidence obtained as a result of a Charter violation that section 24(2) applies to. ${ }^{197}$ For example, it should be noted, that evidence obtained by trick, as occurred in the case of Rothman v. The Queen, ${ }^{198}$ or

195. Id. at 109-110.

196. Id. at 110 .

197. Regina v. Tontarelli \& Davis (1982) 8 W.C.B. 259 (Ont. Co. Ct.).

198. [1981] 1 S.C.R. 640, 20 C.R. (3d) 97. 
through entrapment as in Amato v. The Queen, ${ }^{199}$ might not be within the ambit of section 24(2) because they might not involve Charter violations.

Second, there is nothing in the text of section 24(2) which rules out the application of the section to derivative or secondary evidence. The section's application to such evidence is a reasonable interpretation of the words contained in the section. It should be noted, however, that as the causal connection between the obtaining of the evidence and violation of the Charter becomes more tenuous, there is a greater likelihood that the Courts will rule either that the evidence was not obtained "in a manner that infringed or denied any rights or freedoms guaranteed by the Charter", or that the admission of evidence would not "bring the administration of justice into disrepute".

\section{5. "The Admission of it in the Proceedings Would Bring the Administra- tion of Justice into Disrepute"}

It would appear that, at least initially, the meaning to be attached to this phrase will be derived from the judgment of Mr. Justice Lamer in Rothman v. The Queen. ${ }^{200}$ In that case, the accused was charged with possession of cannabis resin for the purpose of trafficking. During his detention in the jail, the accused made certain inculpatory remarks to an undercover police officer who was placed in his cell. At trial, these remarks were ruled inadmissible, there being a reasonable doubt as to whether they were properly elicited. In the Court of Appeal for Ontario, the Crown appeal was allowed on the basis that the accused did not consider the officer to be "a person in authority" and consequently, the confession rule did not apply. The Court of Appeal went on to state that even if the case was governed by the normal confession rule, the requirements of the rule had been satisfied. The accused's appeal to the Supreme Court of Canada was dismissed on essentially the same grounds as in the Court of Appeal.

Mr. Justice Lamer, concurring in the result, would have added the following test to the normal rules for determining the admissibility of a confession: ${ }^{201}$

A statement made by the accused to a person in authority tendered by the prosecution in a criminal proceeding against him, though elicited under circumstances which would not render it inadmissible, shall nevertheless be excluded if its use in the proceedings would, as a result of what was said or done by any person in authority in eliciting the statement, bring the administration of justice into disrepute. [Emphasis added.]

\section{Justice Lamer elaborated on this rule as follows: ${ }^{202}$}

There must first be a clear connection between the obtaining of the statement and the conduct; furthermore, that conduct must be so shocking as to justify the judicial branch of the criminal justice system in feeling that, short of disassociating itself from such conduct through rejection of the statement, its reputation and, as a result, that of the whole criminal justice system would be brought into disrepute.

The judge, in determining whether under the circumstances the use of the statement in the proceedings would bring the administration of justice into disrepute, should consider all the circumstances of the proceedings, the manner in which the statement was obtained, the degree to

199. (1983) 42 N.R. 487, 29 C.R. (3d) 1 (S.C.C.).

200. Supra n. 198. For example, see Regina v. McIntyre et al (1982) 69 C.C.C. (2d) 162 (Alta. Q.B.); Regina v. Tontarelli and Davis, supra n. 196; Regina v. Collins and Collins, an unreported judgment of Wong Co. Ct. J., delivered October 5, 1982; and Regina v. Caron, an unreported judgment of Bernstein Dist. Ct. J., delivered November 16, 1982.

201. Supra n. 198 at 696.

202. Id. at 696-697. 
which there was a breach of social values, the seriousness of the charge, the effect the exclusion would have on the result of the proceedings. It must also be borne in mind that the investigation of crime and the detection of criminals is not a game to be governed by the Marquess of Queensbury rules. The authorities, dealing with shrewd and of ten sophisticated criminals, must sometimes of necessity resort to tricks or other forms of deceit, and should not through the rule be hampered in their work. What should be repressed vigorously is conduct on their part that shocks the community. That a police officer pretend to be a lockup chaplain and hear a suspect's confession is conduct that shocks the community; so is pretending to be the duty legal aid lawyer, eliciting in that way incriminating statements from suspects or accused; injecting Pentothal into a diabetic suspect, pretending it is his daily shot of insulin, and using his statement in evidence would also shock the community; but, generally speaking, pretending to be a hard drug addict to break a drug ring would not shock the community; nor would as in this case pretending to be a truck driver to secure the conviction of a trafficker; in fact, what would shock the community would be preventing the police from resorting to such a trick. [Emphasis added.]

The "shock the community" test was adopted by Mr. Justice Estey in his dissenting judgment in Amato v. The Queen. ${ }^{203}$ In discussing this case involving entrapment, Mr. Justice Estey stated that the evidence of the crime would be excluded if "the scheme so perpetrated must in all the circumstances be so shocking and outrageous as to bring the administration of justice into disrepute". ${ }^{204}$

This test appears to be highly restrictive. Before the Rothman test is too quickly embraced, certain observations should be made. First, it should be noted that Rothman involved the admissibility of confessions. In proposing his test, Mr. Justice Lamer was putting forth only a minority view. In his dissenting judgment, Mr. Justice Estey, with whom Chief Justice Laskin concurred, spoke about this issue as well. However, he equated the phrase "bring the administration of justice into disrepute" with "prejudice the public interest in the integrity of the judicial process." ${ }^{205}$ Justice Estey stated: ${ }^{206}$

The elements which go into the determination of the voluntariness of that statement include all those circumstances which bear upon the overriding requirement that the admission of the statement will not render the administration of criminal justice unacceptable in the community. [Emphasis added.]

It seems that these comments are inconsistent with the more stringent test proposed by Justice Lamer. None of the justices of the majority commented on this issue.

Second, the case of Amato v. The Queen ${ }^{207}$ involved whether a stay should be issued for an abuse of process. The issuing of a stay is a considerably more drastic remedy than the exclusion of evidence. It can, therefore, be argued that the "shock to the community" test is too restrictive for the determination of whether evidence should be excluded where the violation of a constitutional right is at issue. It does not accord with the responsibility imposed upon the judiciary to safeguard the new regime of rights guaranteed in the Charter.

A less restrictive or more "interventionist" ${ }^{208}$ posture was taken in Regina v. Samson. ${ }^{209}$ In this case, Judge Borins had to determine the

203. Supra n. 199.

204. Id. at 524.

205. Supra n. 198 at 649 .

206. Id. at 656.

207. Supra n. 199.

208. So characterized by Donald R. Stuart in "Annotation: R. v. Samson"(1983) 29 C.R. (3d) 216.

209. (1983) 29 C.R. (3d) 215. 


\section{meaning of section 178.16(2) of the Criminal Code:}

(2) Notwithstanding subsection (1), the judge or magistrate presiding at any proceedings may refuse to admit evidence obtained directly or indirectly as a result of information acquired by interception of a private communication that is itself inadmissible as evidence where he is of the opinion that the admission thereof would bring the administration of justice into disrepute.

Judge Borins first discussed the meaning of the term "the administration of justice". After making reference to the Constitution Act, 1867, and the Administration of Justice Act, ${ }^{210}$ he concluded: ${ }^{211}$

.. "the administration of justice", with particular reference to the criminal law, is a compen.
dious term that stands for all the complexes of activity that operate to bring the substantive law
of crime to bear, or to keep it from coming to bear, on persons who are suspected of having
committed crimes. It refers to the rules of law that govern the detection, investigation, apprehen-
sion, interviewing and trial of persons suspected of crime and those persons whose responsibility
it is to work within these rules. The administration of justice is not confined to the courts; it
encompasses officers of the law and others whose duties arc necessary to ensure that the courts
function effectively. The concern of the administration of justice is the fair, just and impartial
upholding of rights, and punishment of wrongs, according to the rule of law. Judge Borins then went on to discuss the meaning of the term "disrepute". After holding that "disrepute" should be given its ordinary meaning, he adopted the definition of "disrepute" in the Shorter Oxford Dictionary, 3rd ed.: "Loss or absence of reputation; illrepute. . .; to disesteem; to bring into discredit; to defame; to bring an evil name upon (by one's conduct) ...".212 Theoretically, this appears to be a much less restrictive definition than the "shock to the community test" proposed by Justice Lamer in Rothman.

After canvassing numerous authorities and treatises, Judge Borins determined that the dual purposes of the legislation were the protection of privacy and crime control. He then held that the evidence in question should be excluded. ${ }^{213}$ In doing so, Judge Borins stated: ${ }^{214}$

Taking into consideration all the circumstances which I have discussed and the treatises and authorities to which I have referred, it is my opinion that the admission of the derivative evidence would bring the administration of justice into disrepute. This has not been an easy decision to reach, because of its likely effect upon the case for the Crown. However, the fundamental nature of the improprieties, and their magnitude, are such that discredit would be brought to the administration of justice were the court, on the one hand, to condemn the breach of the provisions of Pt. IV.1 by excluding the primary evidence and on the other hand, to excuse the breach by admitting the derivative evidence. The reception of the derivative evidence would appear to be judicial condonation of unacceptable police behaviour. There is no question that the electronic investigation was central to the investigation. This is conceded by counsel for the Crown. That a real concern to the police is the evidence derived from intercepted communications is illustrated by the evidence obtained as a result of the unlawful interceptions in this case. To exclude primary evidence and to admit evidence derivative of it will, in my opinion, have no deterrent effect on police conduct. While it may appear that the unlawfully intercepted communications which gave rise to the derivative evidence may represent but a small percentage of the total interceptions, what is of significance is that they issued from and formed part of a larger electronic surveillance operation. Viewed separately and in the larger context, they are characterized by a fundamental misconception on the part of the investigating officers of the purposes, procedural requirements and substantive safeguards provided by Pt. IV.1 of the Criminal Code.

What has occurred in this case is a serious breach in the right to privacy provided by Pt. IV.1 of the Criminal Code. I believe that, were the court to simply ignore the breach of this right or to excuse it with words of reprobation, this would bring the administration of justice into disrepute. This was a breach of the law by those whose duty to enforce the law goes hand in hand with their duty to obey it. [Emphasis added.]

210. R.S.O. 1980 , c. 6.

211. Supra n. 209 at 228.

212. Id. at 229.

213. This is one of the few cases where evidence has been excluded pursuant to s. 178.16(2).

214. Supra n. 209 at 239.40 . 
If one of the purposes of section 24(2) is to provide for the exclusion of evidence as a method of controlling the conduct of the authorities, then the position taken in Samson appears to be more protective of civil liberties than the test in Rothman.

However, two factors might alleviate the stringency of the Rothman test. First, the English version of section 24(2) uses the phrase "would bring" while the French version uses the term "est susceptible". In the English version an applicant would have to show the probability of the administration of justice being brought into disrepute. On the other hand, the French version speaks only of the possibility. It would appear from this that the French version would place a less onerous burden upon the applicant than does the English version. Second, it has been suggested by one commentator ${ }^{215}$ that the phrases "disrepute" and "deconsiderer" in the French version do not import the same meaning. In particular, he suggests that "disrepute" implies a disgrace in the community generally while "deconsiderer" implies a discredit to those involved with the criminal justice system itself. It should be noted that in the case of Regina $\mathrm{v}$. McIntyre et al,"16 Madame Justice Veit adopted the French version "est susceptible" but then applied the test of Justice Lamer in Rothman to rule evidence obtained from an illegal search admissible in the case.

\section{6. "Having Regard to all the Circumstances"}

Section 24(2) provides that evidence is to be excluded if its admission in the proceeding would bring the administration of justice into disrepute in the circumstances of the case. To some extent we have already discussed those factors that will be considered in determining if the administration of justice will be brought into disrepute. ${ }^{217}$ In Regina v. Samson, Judge Borins, in considering similar wording in section 178.16(2) of the Criminal Code, stated: ${ }^{218}$

While it is neither possible not desirable to attempt an exhaustive catalogue of considerations appropriate to a determination of what would or would not bring the administration of justice into disrepute, in my view, depending upon the facts of a particular case, the following factors may be relevant. The impropriety resulting in the unlawful interception may be trivial or technical ... On the other hand, the impropriety may be serious, in the sense that it represents a disregard of the legislation per se, a disregard of the terms or conditions of an authorization, or a substantial disregard of that policy inherent in the legislation securing the right of privacy. Whether the evidence was obtained as a result of deliberate action on the part of the police or whether it was obtained as a result of ignorance, mistake or error in judgment may also be of significance. It would be important to know whether the method of surveillance used was as a result of a deliberate policy to employ that method and whether the reception of the evidence would tend to encourage such a policy. It would in some cases be important to know whether urgent circumstances existed which required the police to act as they did to prevent the destruction or loss of evidence. The seriousness of the crime alleged, in some cases, may be of signifi. cance. Because Parliament has prescribed in detail, in the interests of assuring the privacy of persons, a special procedure to be followed in obtaining evidence by means of electronic surveillance, it will be important to know why the police departed from the statutory procedure. The extent of the failure to adhere to the legislation or the terms of an authorization will also be significant; a single lapse may not attract exclusion, whereas widespread deviation may do so. Finally, I believe that it is necessary to bear in mind that, while s. 178.11(1) . . does not attract criminal liability unless the interception is "wilful", the circumstances under which exclusion of evidence may result are not necessarily the same as those under which a criminal violation of $\mathrm{Pt}$. IV. 1 would be found.

215. Muldoon, "Notes for a Panel Presentation on Evidence Obtained by an Illegal Means or in a Manner Which Infringes any Rights or Freedoms Guaranteed by the Canadian Charter of Rights and Freedoms", (unpublished).

216. Supra n. 200.

217. Supra $\mathrm{n} .99$ and 100 and accompanying text.

218. Supra n. 209 at 234.235. 
The following queries ${ }^{219}$ seem to be those most commonly raised for consideration in determining whether the administration of justice has been brought into disrepute in a particular case.

a. Was the Charter violation part of a deliberate plan to obtain the evidence?

The MacDonald Royal Commission into Certain Activities of the Royal Canadian Mounted Police recognized this factor as being of prime importance. Their report contains the following passage: ${ }^{220}$

We would like to refer specifically to two of the factors which the Law Reform Commission's proposed section would require the court to take into account. The first is the extent to which the violation was wilful and the police officer's ignorance inexcusable. We have already observed that if one purpose of the rule is to deter illegal conduct by the police it makes little sense to exclude the evidence if the officer's conduct was inadvertent. Moreover, if the officer's conduct was not culpable, the integrity of the court is not so much in jeopardy if the evidence is admitted. However, if only the wilfulness of the violation were to be considered this would place a premium on the ignorance of the officer. Therefore, to ensure that police forces are motivated to train and educate officers adequately, the Court should be required to consider whether the officers ignorance was inexcusable. This would, we hope, have the effect, in the case of an inadvertent error, of requiring the Judge to determine whether adequate police training procedures were undertaken.

The deliberate nature of the illegality was also considered in the Fairley case $^{221}$ and the People v. O'Laughlin. ${ }^{222}$ It also played a part in the recent decisions of Regina v. Sogz $z^{223}$ and Regina v. Christian. ${ }^{224}$

b. Is the Charter violation serious or of a trivial or technical nature?

This question is directed to whether the Charter violation is of a technical nature or is a substantial infringement or denial of the individual's right. For example, in Regina v. Hynds, ${ }^{225}$ the Court held that a wrong digit in a search warrant would not operate to exclude evidence obtained during the search.

c. Were the perpetrators of the Charter violation law officers or private citizens?

It would appear from this question that if the illegality is perpetrated by a law officer there is a greater probability that it will be excluded under the discretion provided in section $24(2)$ than if it is perpetrated by a private citizen.

d. Under the circumstances, was it reasonably possible to conform to the requirements of the Charter?

In the case of McGovern v. H.M. Advocate, ${ }^{226}$ the exclusion of evidence seemed to turn upon the fact that the law officers failed to apply the proper order of procedure. It is clear on the case that the correct procedure could just as easily have been applied. Further, it would appear that if the motivation behind the denial of the person's rights under the Charter were a matter of urgency, for example to preserve evidence before its possible

219. Adapted, in part, from Law Reform Commission of Canada, Study Paper No. 10: Exclusion of Illegally Obtained Evidence (1974) at 16.

220. Supra n. 107 at 1045-1046.

221. Supran. 127.

222. Supra n. 146.

223. (1982) 8 W.C.B. 104 (B.C.S.C.).

224. (1982) 7 W.C.B. 467 (Ont. Prov. Ct.).

225. (1983) 70 C.C.C. (2d) 186 (Alta. Q.B.).

226. Supra n. 126. 
destruction or to prevent the immediate continuation of some dangerous criminal act, then police officers might be justified in infringing the rights and freedoms guaranteed by the Charter. A further consideration in this regard would be whether the means used to obtain the evidence was the only practical means available for the effective detection of the crime. This would engender discussion of whether the authorities had used the method of crime detection which was the least detrimental to the person's rights under the Charter.

e. Is the crime of which the defendant stands accused a serious crime?

This factor, once again, was considered by the MacDonald Royal Commission. In the report of the Commission the following passage is found:227

... the seriousness of the offence for which the accused is charged is a factor to be considered. An exclusionary rule that does not permit consideration of the seriousness of the crime produces a risk that dangerous offenders will more frequently be returned to the community and that the rule will be self-defeating. Instead of appreciating the moral purity of the Court system and internalizing values of due process, citizens will see the system as the champion of errant technicality at the expense of other more humane values. Moreover, in terms of deterrents to police officers, it is in serious cases that it is most likely that alternatives to the exclusionary rule will be most effective.

We recognize, consequently, that the exclusionary discretion is likely to be exercised in favour of excluding the illegally obtained evidence in minor criminal cases. In serious criminal cases, such as murder, the trial judge is likely to admit the evidence.

However, it should be noted that in the Australian case of Regina v. Ireland, ${ }^{228}$ photographs of the accused's hand as well as an account of the medical examination of the accused's hand were both ruled inadmissible in a murder prosecution.

One might well conclude this section by asking why an individual's constitutional rights are less protected from accidental violations than from deliberate ones. Further, what difference should it make if the constitutional violation was serious or merely technical in nature? Or why should one's rights be less protected when charged with a serious crime as opposed to a minor one?

These are all relevant questions but are ultimately directed to the appropriateness of the exclusionary section. At the time section 24(2) was drafted, certain philosophical accommodations were made. A balance was struck between the objective of preserving civil liberties, on the one hand, and ensuring effective police detection of criminal activities on the other. No absolute rule of admission (as provided in the Wray case) is proposed but neither is there an absolute rule of exclusion (as in the American jurisprudence). If the courts in each individual case are going to balance the competing policy concerns, it is submitted, the above mentioned factors will be important in the process of constitutional decision-making.

A final observation on section 24(2) may be appropriate. One overall criticism might be leveled at the section. Assuming the use of Mr. Justice Lamer's test in Rothman, whether the admission of a particular piece of evidence would bring the administration of justice into disrepute, is an empirical question. The courts when faced with this issue will not construct and administer empirical tests to determine the feelings and

227. Supra n. 107 at 1046.

228. Supra n. 133. 
beliefs of either the community at large, or of the legal community in particular. In each case, based upon his or her own value system, the judge will decide whether or not, in his or her view, admission of the evidence would bring the administration of justice into disrepute. The test puts forth a false notion of objectivity. In fact, the determination will largely depend upon the personal background, experience, and value system of the individual trial Judge.

\section{CONCLUSION}

This article has canvassed the main issues which counsel and the courts are likely to face in the interpretation and application of section 24 of the Charter of Rights and Freedoms. Much of the discussion found herein is of a highly speculative nature. This is inevitable given that the Charter creates a new constitutional regime for the protection of individual rights and freedoms. However, the importance of the enforcement section cannot be overestimated. Through the vehicle of section 24, the courts will give effect to the rights and freedoms guaranteed in the Charter. 